PNL-9826 Rev. 2

UC-812

\title{
REVIEW OF ALARA PLAN FOR ACTIVITIES AT THE 105 K-EAST FUEL STORAGE BASIN
}

\author{
G. J. Vargo \\ J. S. Durham \\ E. E. Hickey \\ P. S. Stansbury \\ G. R. Cicotte
}

September 1994

Prepared for

the U.S. Department of Energy

under Contract DE-AC06-76RLO 1830

Pacific Northwest Laboratory

Richland, Washington 99352 


\section{DISCLAIMER}

This report was prepared as an account of work sponsored by an agency of the United States Government. Neither the United States Government nor any agency thereof, nor any of their employees, make any warranty, express or implied, or assumes any legal liability or responsibility for the accuracy, completeness, or usefulness of any information, apparatus, product, or process disclosed, or represents that its use would not infringe privately owned rights. Reference herein to any specific commercial product, process, or service by trade name, trademark, manufacturer, or otherwise does not necessarily constitute or imply its endorsement, recommendation, or favoring by the United States Government or any agency thereof. The views and opinions of authors expressed herein do not necessarily state or reflect those of the United States Government or any agency thereof. 


\section{DISCLAIMER}

Portions of this document may be illegible in electronic image products. Images are produced from the best available original document. 


\section{Summary}

As part of its ongoing efforts to reduce doses to workers to levels as low as reasonably achievable (ALARA), Westinghouse Hanford Company (WHC) tasked the Health Protection Department of the Pacific Northwest Laboratory (PNL) to review operations at the $105 \mathrm{~K}$-East Fuel Storage Basin (105 K-East). This review included both routine operations and a proposed campaign to encapsulate $\mathrm{N}$-Reactor fuel stored there.

This report summarizes the results of PNL's reviews of policy, procedures, and practices for operations at $105 \mathrm{~K}$-East as well as an evaluation of the major sources of occupational radiation exposures. Where possible, data previously collected by WHC and its predecessors were used. In addition, PNL staff developed a three-dimensional model of the radiological environment within $105 \mathrm{~K}$-East to assess the relative contributions of different radiation sources to worker dose and to provide a decision tool for use in evaluating alternative methods of dose rate reduction.

The model developed by PNL indicates that for most areas in the basin the primary source of occupational radiation exposure is the contaminated concrete surfaces of the basin near the waterline. Basin cooling water piping represents a significant source in a number of areas, particularly the Technical Viewing Pit. This report contains specific recommendations to reduce the impact of these sources of occupational radiation exposure in $105 \mathrm{~K}$-East. Other recommendations to reduce doses to workers during activities such as filter changes and filter sampling are also included. 



\section{Contents}

Summary $\quad \ldots \ldots \ldots \ldots \ldots \ldots \ldots \ldots \ldots \ldots \ldots \ldots \ldots \ldots \ldots \ldots \ldots$ ii

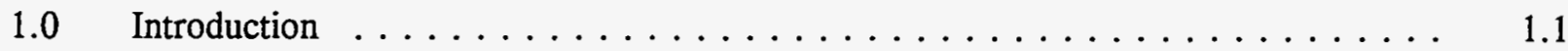

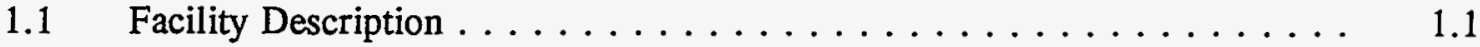

$1.2 \quad$ Radiological Characteristics . . . . . . . . . . . . . . 1.2

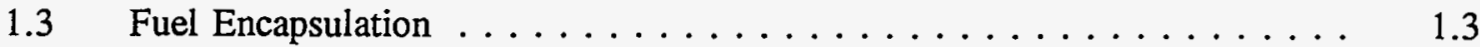

1.4 Summary of Prior Efforts and Experiments $\ldots \ldots \ldots \ldots \ldots \ldots \ldots$

1.4.1 Segregation Campaign $\ldots \ldots \ldots \ldots \ldots \ldots \ldots \ldots$

1.4.2 Contractor Studies $\ldots \ldots \ldots \ldots \ldots \ldots \ldots \ldots \ldots \ldots$

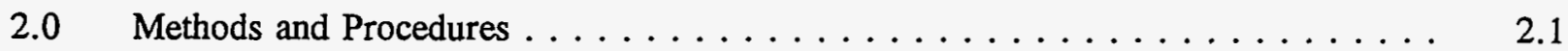

2.1 Guidance Documents Reviewed $\ldots \ldots \ldots \ldots \ldots \ldots \ldots$

2.2 WHC Documents Reviewed $\ldots \ldots \ldots \ldots \ldots \ldots \ldots \ldots \ldots \ldots \ldots$

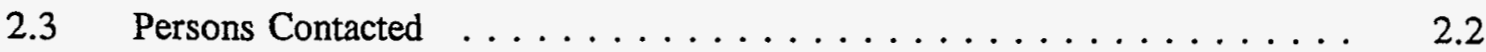

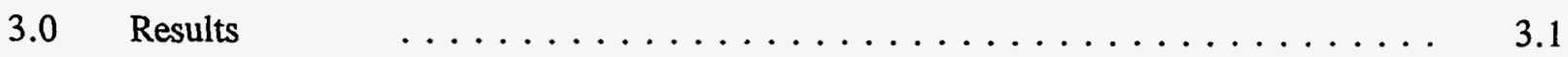

$3.1 \quad$ Policies, Programs, and Procedures . . . . . . . . . . . . . 3.1

3.1.1 Radiological Control Program . . . . . . . . . . . . . 3.1

3.1.2 WHC's ALARA Program . . . . . . . . . . . . 3.1

3.2 Organization, Staffing, and Training $\ldots \ldots \ldots \ldots . \ldots \ldots \ldots$

3.2 .1 Organization $\ldots \ldots \ldots \ldots \ldots \ldots \ldots \ldots \ldots \ldots \ldots \ldots$

3.2.2 Training and Qualification $\ldots \ldots \ldots \ldots \ldots . \ldots \ldots$

$3.3 \quad$ ALARA Program Implementation $\ldots \ldots \ldots \ldots \ldots \ldots \ldots$

3.3.1 Collective Dose History . . . . . . . . . . . . . . 3.4

3.3.2 Collective Dose Projections and Goals . . . . . . . . . . . 3.4

V Rev. 2 
3.4 . Radiological Source Term . . . . . . . . . . . . . . 3.6

3.4.1 Fuel Storage Basin Water $\ldots \ldots \ldots \ldots \ldots \ldots \ldots \ldots$

3.4.2 Contaminated Concrete Surfaces . . . . . . . . . . . . . 3.6

3.4.3 Fuel Storage Basin Water Systems $\ldots \ldots \ldots \ldots \ldots \ldots . \ldots . \ldots$

3.4 .4 Dose Model $\ldots \ldots \ldots \ldots \ldots \ldots \ldots \ldots \ldots \ldots \ldots \ldots$

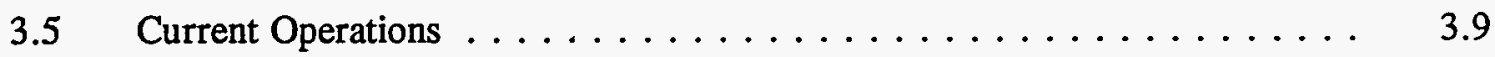

3.5.1 Spent Cartridge Filter Replacement . . . . . . . . . . . . 3.9

3.5.2. Ion Exchange Column Replacement . . . . . . . . . . . . 3.10

3.5.3 Ion Exchange Module Operation and Replacement $\ldots \ldots \ldots . . . .3 .11$

3.5.4 Sand Filter Sampling . . . . . . . . . . . . . . 3.11

3.6 Encapsulation Campaign $\ldots \ldots \ldots \ldots \ldots \ldots \ldots \ldots \ldots \ldots \ldots \ldots$

3.6.1 Proposed Encapsulation Method . . . . . . . . . . . 3.12

3.6.2 Canister Disposal Alternatives . . . . . . . . . . 3.13

3.6.3 Time-Motion Study $\ldots \ldots \ldots \ldots \ldots \ldots \ldots \ldots \ldots \ldots$

3.6.4 Dose Projection $\ldots \ldots \ldots \ldots \ldots \ldots \ldots \ldots \ldots \ldots \ldots$

3.7 Review of Related DOE and Commercial Nuclear Industry Experience . . . $\quad 3.24$

3.7.1 DOE Experience $\ldots \ldots \ldots \ldots \ldots \ldots \ldots \ldots \ldots \ldots \ldots . \ldots \ldots$

3.7.2 Commercial Nuclear Industry Experience . . . . . . . . . . . 3.24

3.7.2.1 Events Involving Objects Surfacing in the SFS Pool $\ldots . .3 .25$

3.7.2.2 Events Involving Highly Radioactive Particles or Fragments of Radioactive Material Removed from SFS Pools . . . . . . . . . . . . . 3.25

3.7.2.3 Event Involving Inadvertent Lifting of Highly Radioactive Material by Hoist . . . . . . . . . . 3.26

3.7.2.4 Event Involving Radiation Streaming $\ldots \ldots \ldots \ldots . \ldots 3.27$

3.7.2.5 Discussion $\ldots \ldots \ldots \ldots \ldots \ldots \ldots \ldots \ldots \ldots \ldots$

Rev. 2 
$4.1 \quad$ Policies, Programs, and Procedures $\ldots \ldots \ldots \ldots \ldots \ldots \ldots \ldots$

4.1.1 Revise Current ALARA Program Manual . . . . . . . . . . . 4.1

4.2 Organization, Staffing, and Training $\ldots \ldots \ldots \ldots \ldots \ldots \ldots \ldots \ldots$

4.2.1 Re-evaluate the Pool of Operators Available
for Encapsulation $\ldots \ldots \ldots \ldots \ldots \ldots \ldots \ldots . \ldots \ldots$

4.2.2 Provide Mockup Training for Fuel Handling . . . . . . . . . . 4.2

4.2.3 Provide Increased Training for Health Physics Technicians . . . . . 4.2

$4.3 \quad$ ALARA Program Implementation $\ldots \ldots \ldots \ldots \ldots \ldots \ldots \ldots \ldots$

4.3.1 Provide Continuous Dose Rate Monitoring for Workers in the $105 \mathrm{KE} \mathrm{FSB} \ldots \ldots \ldots \ldots \ldots . \ldots \ldots . \ldots \ldots$

4.3.2 Provide ALARA Areas for Workers . . . . . . . . . . 4.3

4.3.3 Provide Increased Access to WRAM and Job Control Systems . . . 4.3

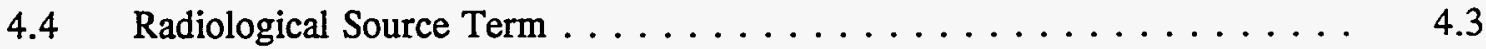

4.4.1 Increase Basin Water Level . . . . . . . . . . . . . . . 4.3

4.4.2 Decontaminate the Basin Cooling Water System Piping
in the Discharge Chute Area $\ldots \ldots \ldots \ldots \ldots . \ldots . \ldots . \ldots$

$4.5 \quad$ Current Operations $\ldots \ldots \ldots \ldots \ldots \ldots \ldots \ldots \ldots \ldots \ldots \ldots$

4.5.1 Cartridge Filter Replacement . . . . . . . . . . . . . 4.4

4.5.2 Ion Exchange Column Replacement . . . . . . . . . . . . 4.6

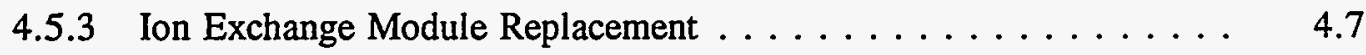

4.5 .4 Sand Filter Sampling $\ldots \ldots \ldots \ldots \ldots \ldots \ldots \ldots \ldots$

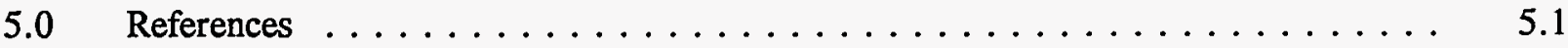




\section{Figures}

$1.1 \quad$ Plan View of K-East Basin $\ldots \ldots \ldots \ldots \ldots \ldots \ldots \ldots \ldots$

1.2 Water Recirculation and Treatment Systems $\ldots \ldots \ldots \ldots$

1.3 Typical K-East Basins Radiation Exposure Rates $\ldots \ldots \ldots \ldots \ldots$

1.4 Schematic of the Fuel Encapsulation Process $\ldots \ldots \ldots \ldots \ldots$

1.5 General Work Arrangement $\ldots \ldots \ldots \ldots \ldots \ldots \ldots \ldots$

1.6 Isometric View of $105 \mathrm{~K}$-East Basin Showing Technical Viewing Pit . . . . . . 1.10

1.7 Proposed Equipment Arangement for Encapsulation Pilot Campaign

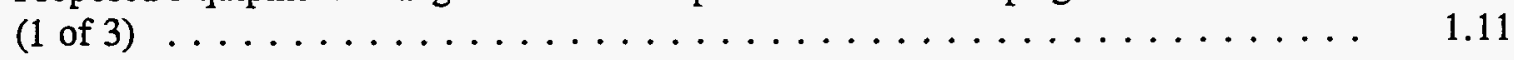

1.8 Proposed Equipment Arrangment for Encapsulation Pilot Campaign

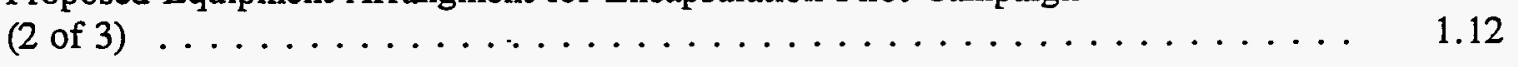

1.9 Proposed Equipment Arrangement for Encapsulation Pilot Campaign

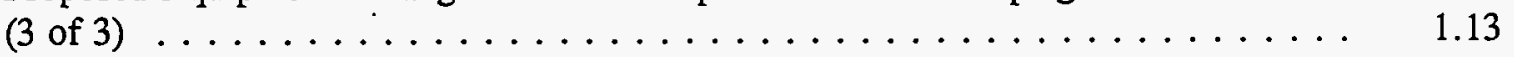

3.1 Schematic Diagram of the Radiological Model Used to Calculate

Doses from the Bathrub Ring and the Basin Water . . . . . . . . . . . . . 3.29

3.2 Schematic Diagram of the Radiological Model Used to Calculate

Doses from the Water Return Lines and Primary Water Header . . . . . . . . . . 3.30

3.3 Basin Cooling Water System Piping Showing Major Contributors

to Personnel Doses in the Technical Viewing Pit Area . . . . . . . . . . . . 3.31

Rev. 2

viii 


\section{Tables}

3.1 Administrative Control Levels and Cognizant Officials . . . . . . . . . . . . 3.2

3.2 Collective Doses, $1992-1993 \ldots \ldots \ldots \ldots \ldots \ldots \ldots \ldots$

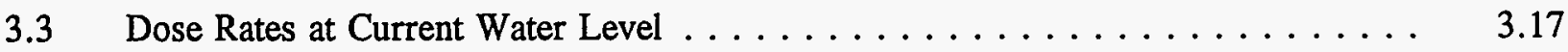

3.4 Dose Rates When Water Level Is 16 Inches $(40.6 \mathrm{~cm})$ Below Current Water Level . 3.18

3.5 Dose Rates When Water Level Is 8 Inches $(20.3 \mathrm{~cm})$ Below Current Water Level . . $\quad 3.18$

3.6 Dose Rates When Water Level Is 4 Inches $(10.2 \mathrm{~cm})$ Below Current Water Level . . 3.19

3.7 Dose Rates When Water Level Is 2 Inches $(5 \mathrm{~cm})$ Below Current Water Level . . . $\quad 3.19$

3.8 Dose Rates When Water Level Is 6 Inches $(15.2 \mathrm{~cm})$ Above Top of Source . . . . 3.20

3.9 Dose Rates When Water Level Is 12 Inches $(30.5 \mathrm{~cm})$ Above Current Water Level . $\quad 3.20$

3.10 Dose Rates When Water Level Is 18 Inches $(45.7 \mathrm{~cm}$ ) Above Current Water Level . 3.21

3.11 Dose Rates When Water Level Is at Current Level and Water Shield Is in Place . . 3.21

3.12 Dose Summary per Canister Using the Discharge Chute for Encapsulation $\ldots \ldots .22$

3.13 Dose Summary per Canister Using the Technical Viewing Pit for Encapsulation . . . 3.22

3.14 Collective Dose Projection for Canister Disposal Campaign, Water at Current Level . . . . . . . . . . . . . . . . . . . 3.24

3.15 Collective Dose Proejct for Canister Disposal Campaign,

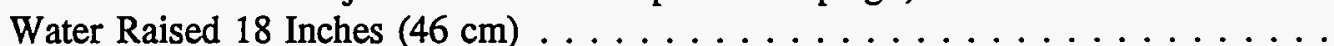




\subsection{Introduction}

Westinghouse Hanford Company (WHC), the Maintenance and Operations (M\&O) contractor for the Hanford Site, has responsibility for operation of the $105 \mathrm{~K}$-East and K-West fuel storage basins (FSBs) in the 100-K Area of the Site. In December 1993, WHC requested that the Health Protection Department of the Pacific Northwest Laboratory (PNL) evaluate current radiological conditions in the $105 \mathrm{~K}$-East Fuel Storage Basin and measures taken, or planned, to maintain doses to workers as low as reasonably achievable (ALARA) both during routine operations at the basin and during a fuel encapsulation campaign scheduled to begin in June 1994. From this evaluation, recommendations that can be reliably implemented by June 1994 were to be provided that could reduce the K-East Basin source term, thus reducing personnel exposure.

The fuel encapsulation campaign has the potential to result in significant personnel exposure. One estimate for the total exposure to be received by approximately 40 personnel over a two-year period was 140 person-rems (Bricker 1991). Such a collective dose could represent $5 \%$ of the total occupational radiation dose received in a year throughout the entire DOE complex.

\subsection{Facility Description}

The K-East Basin and its companion in the $105 \mathrm{~K}$-West facility are large concrete pools $125 \mathrm{ft}$ $(38 \mathrm{~m})$ long, $67 \mathrm{ft}(20 \mathrm{~m})$ wide, and $21 \mathrm{ft}(6.4 \mathrm{~m})$ deep, with current water level maintained at $16 \mathrm{ft}$ $(4.8 \mathrm{~m})$. Figure 1.1 shows a plan view of such a basin. The basin holds approximately 1 million gallons (3.7 million L). Constructed in 1951, the pools have been used for interim storage of irradiated N-Reactor fuel since 1975 (K-East) and 1981 (K-West).

The K-East Basin contains 1,150 metric tons of uranium (MTU) in the form of irradiated fuel from N-Reactor stored in 3,668 open canisters (DOE 1992). This fuel was discharged between 6 years and 23 years ago. A study concluded 13 years ago that approximately $6 \%$ of this fuel had sustained cladding damage as a result of discharge from $\mathrm{N}$-Reactor and subsequent handling (Bechtold 1981). More recent observations suggest that up to $50 \%$ of fuel stored in K-East Basin may have damaged, leaking cladding (Larson 1993). In addition, debris (e.g., fuel clips, hand tools, personal items, etc.) and sediment have accumulated on the basin floor. There is an estimated $770 \mathrm{ft}^{3}\left(22 \mathrm{~m}^{3}\right)$ of accumulated sediment.

When the original report PNL-9826 was developed, WHC indicated that they planned to use the discharge chute area as a primary work location for fuel encapsulation activities. Because of the discovery of an unreviewed safety question (USQ) regarding the seismic qualification of a concrete construction joint in the discharge chute area, the original plans to perform encapsulation work in this area have been changed and present plans include the installation of encapsulation equipment in the Technical Viewing Pit located on the west wide of the basin. The discussion and recommendations 
for reducing personnel doses in the discharge chute area are retained in this report in the event that the USQ becomes resolved, allowing this area to be used for encapsulation activities.

The discharge chute consists of a large concrete platform covered and surrounded by a grating. A railing is located $1 \mathrm{ft}(30.5 \mathrm{~cm})$ south of the platform; most of the fuel-handling activities will be performed while the worker stands on the grating between the platform and the railing. While standing on the grating above the discharge chute, a worker does not benefit from the shielding provided by the platform, and the worker is in close proximity to the source presented by the "bathtub ring" near the waterline. In addition, a 5-in. (12.7-cm) riser has been installed between the railing and the platform. The riser extends from the railing and covers the southern $2 \mathrm{ft}(61 \mathrm{~cm})$ of the platform.

The Technical Viewing Pit is one of three service pits located on the west wide of the $105 \mathrm{~K}$-East Basin. This pit, illustrated in Figures 1.6 through 1.9, consists of two bays, each of which is equipped with a gate and lead to a viewing pit. The western portion of the pit is divided into segments, the eastern of which is of the same depth as the entrance bays and remainder of the basin (20'9" [6.3 m]); the western segment, separated by a divider wall that extends above the present basin water level is hallower $(10 \mathrm{ft}[3.1 \mathrm{~m}])$ and is maintained dry. The cartridge filter systems, described in section 3.4.3 and illustrated in Figure 1.5, is installed in the deeper portion of the Technical Viewing Pit. The shallow (western) end of the pit is used for handling spent cartridge filters.

\subsection{Radiological Characteristics}

In 1993, it was estimated that the fuel in the K-East Basin contains nine million curies of radioactivity with the dominant radionuclies being plutonium isotopes, ${ }^{137} \mathrm{Cs}$, and ${ }^{90} \mathrm{Sr}$ in roughly equal proportions (Watson 1993). The ${ }^{137} \mathrm{Cs}$ concentrations are on the order of $1 \mu \mathrm{Ci} / \mathrm{L}$ to $5 \mu \mathrm{Ci} / \mathrm{L}$ $(40 \mathrm{kBq} / \mathrm{L}$ to $200 \mathrm{kBq} / \mathrm{L})$. There is also tritium present at a concentration of $3 \mu \mathrm{Ci} / \mathrm{L}(120 \mathrm{kBq} / \mathrm{L})$. Trace amounts (a few picocuries per milliliter) of other radionuclides are present.

A small fraction of radioactive material in the fuel has leached into the basin's 1 million gallons (3.7 million L) of water. Because of the damaged fuel element cladding, this release of radionuclides is expected to continue. Two systems of filters and ion exchange water purifiers are in operation to control the amount of radioactivity and other undesirable contamination in the water. Figure 1.2 illustrates these systems.

The sediment in the bottom of the K-East Basin is formed by insoluble compounds of mostly aluminum, iron, manganese, and uranium; deriving from degraded fuel and storage containers. The chemistry of this "sludge" is complicated, involving hydroxides that form in the presence of dissolved oxygen and a nearly neutral $\mathrm{pH}$. Larger particles formed by the flocculation of smaller particles and may contain elements one would otherwise think of as soluble. Seventeen percent of the basin sludge is uranium. 
Figure 1.3 shows typical radiation exposure rates $(\mathrm{mrem} / \mathrm{h}$ ) measured during a routine radiation survey of the K-East Basin completed during February 1994. Not shown are some of the contact dose rates around the water cooling system intake and return piping. These rates are generally 100 to $200 \mathrm{mrem} / \mathrm{h}$. The pipes near the discharge chute have been shielded with lead, reducing the dose rates in the vicinity by a factor of two or three.

External exposure is caused primarily by ${ }^{137} \mathrm{Cs}$. The three sources of such exposure are, in order of the relative dose contribution, the basin walls, where ${ }^{137} \mathrm{Cs}$ has been deposited on the concrete near the waterline (or bathtub ring), corrosion deposits in the piping of the water cooling system, and the basin water itself.

\subsection{Fuel Encapsulation}

Figure 1.4 briefly summarizes the process that will be used to encapsulate the fuel. More details can be found in the Environmental Assessment for the project (DOE 1992). While Figure 1.4 shows the encapsulation activities being performed in the discharge chute area, these activities will be relocated to the Technical Viewing Pit described earlier. The entire process will be performed while the fuel remains under water. Figure 1.5 shows the general work arrange-ment for moving fuel in the storage basin. A minimum of $10 \mathrm{ft}(3 \mathrm{~m})$ of water will be maintained to shield workers from the intense radiation fields around the spent fuel.

\subsection{Summary of Prior Efforts and Experiments}

The $105 \mathrm{~K}$-East and $105 \mathrm{~K}$-West Reactors were shut down in January 1971. The fuel storage facilities at these reactors were intended for short-term cooling and shielding of irradiated fuel, typically 150 to 180 days. When the basins were built, the walls consisted of unpainted concrete. During an extended standby at the PUREX facility (1972-1983), significant amounts of irradiated fuel accumulated at the N-Reactor. In 1975, the $105 \mathrm{~K}$-East Basin was placed in service for the storage of irradiated $\mathrm{N}$-Reactor fuel. Storage was initiated with minimal modifications to the facility. In order to repair known leaks, the $105 \mathrm{~K}$-West Basin was drained, repaired, and the concrete surfaces coated with an epoxy resin prior to being placed into service in 1981 for storage of additional N-Reactor fuel. Original plans called for these basins to be emptied over a 3-to-4-year period; however, subsequent PUREX operations did not process the entire inventory prior to ceasing operations in March 1990. 


\subsubsection{Segregation Campaign}

During 1983 and 1984, a segregation campaign was conducted in the $105 \mathrm{~K}$-East and K-West Basins to sort fuel according to its enrichment and exposure. Many of the planning assumptions and time estimates for the encapsulation campaign are based on anecdotal knowledge gained during this effort.

\subsubsection{Contractor Studies}

Because of the relatively short schedule for this study, much of the data used was taken from studies performed by WHC and its predecessors. In particular, KE Fuel Storage Basin Activity Mapping in Support of Exposure Reduction (Bechtold 1981) provided a large portion of the data used to model the radiological characteristics of the concrete basin.

Figure 1.6 shows a view of the solids model for the $105 \mathrm{~K}$-East Basin and an overview of the Technical Viewing Pit area that is proposed for use in the encapsulation campaign. Figures 1.7 through 1.9 show the proposed layout of encapsulation equipment in the Technical Viewing Pit area.

Rev. 2 


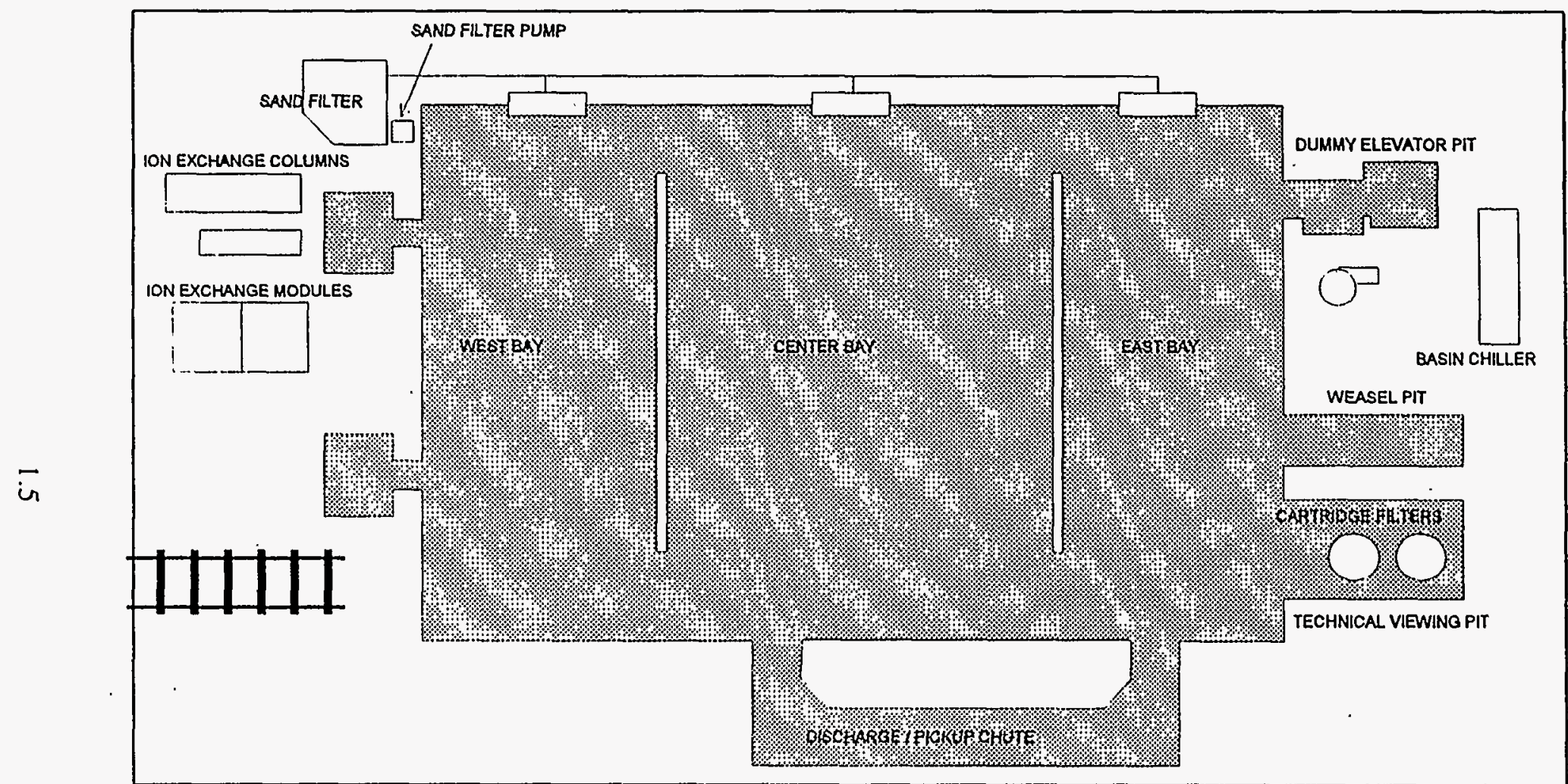

Figure 1.1. Plan View of K-East Basin 


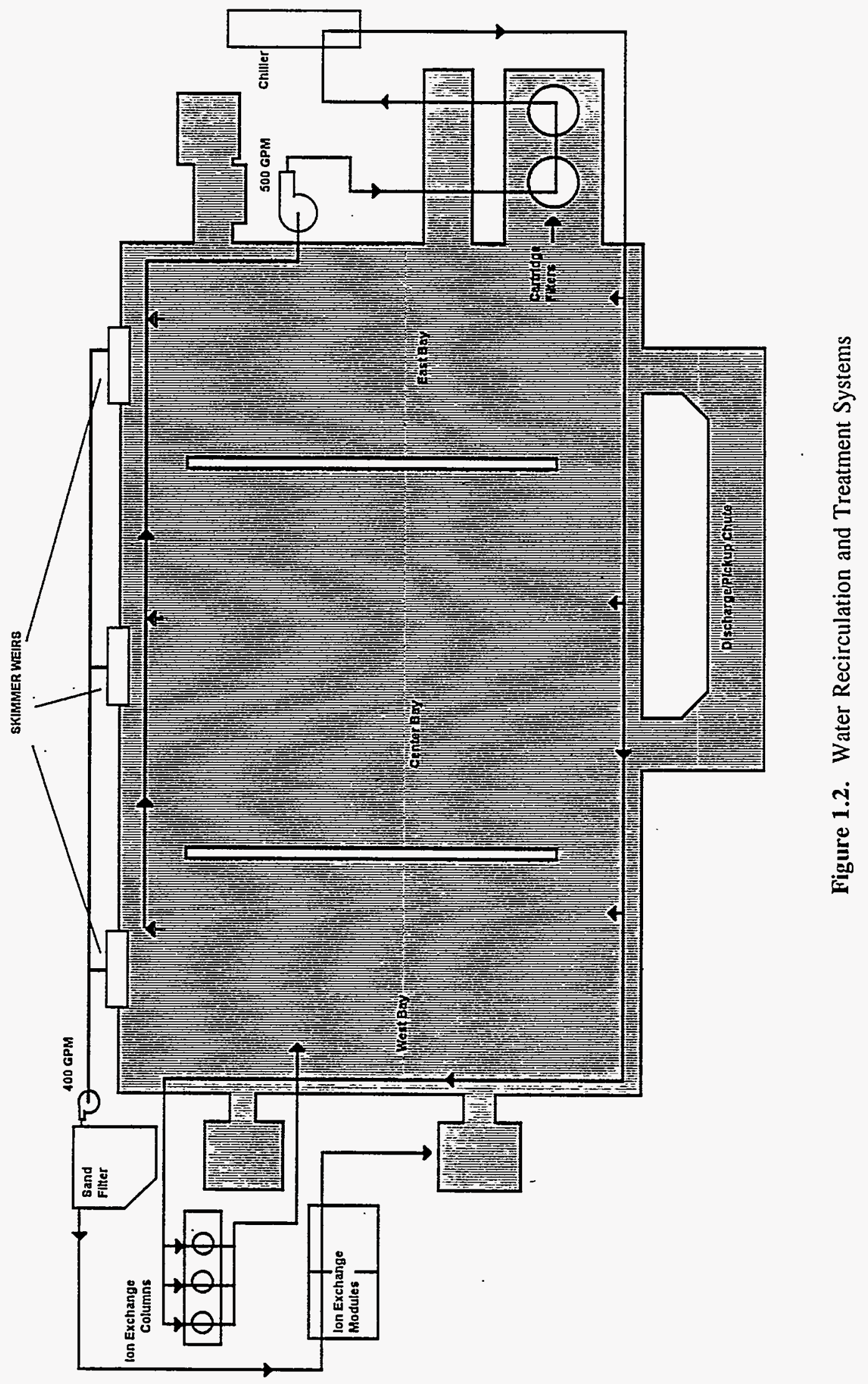

Rev. 2 


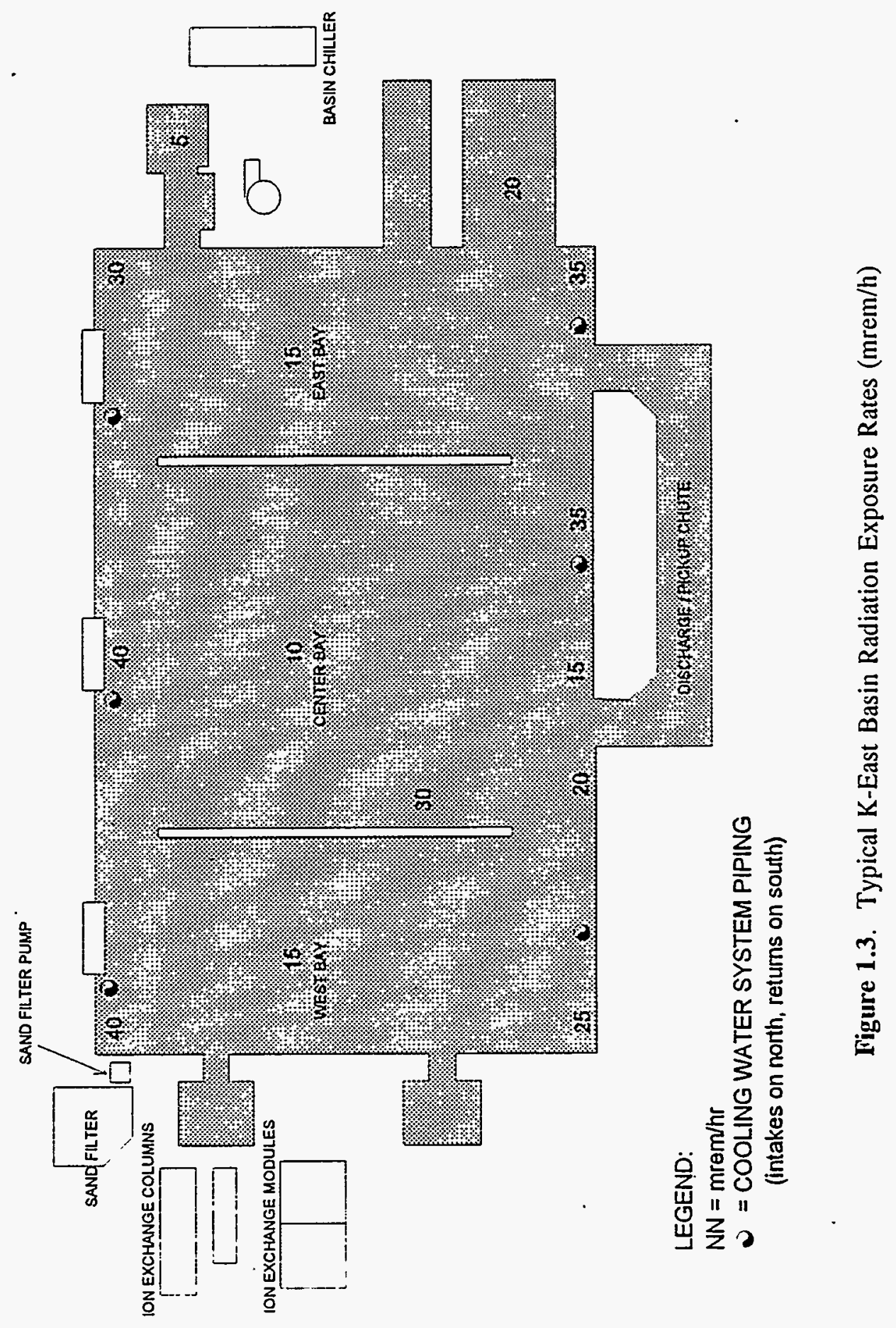




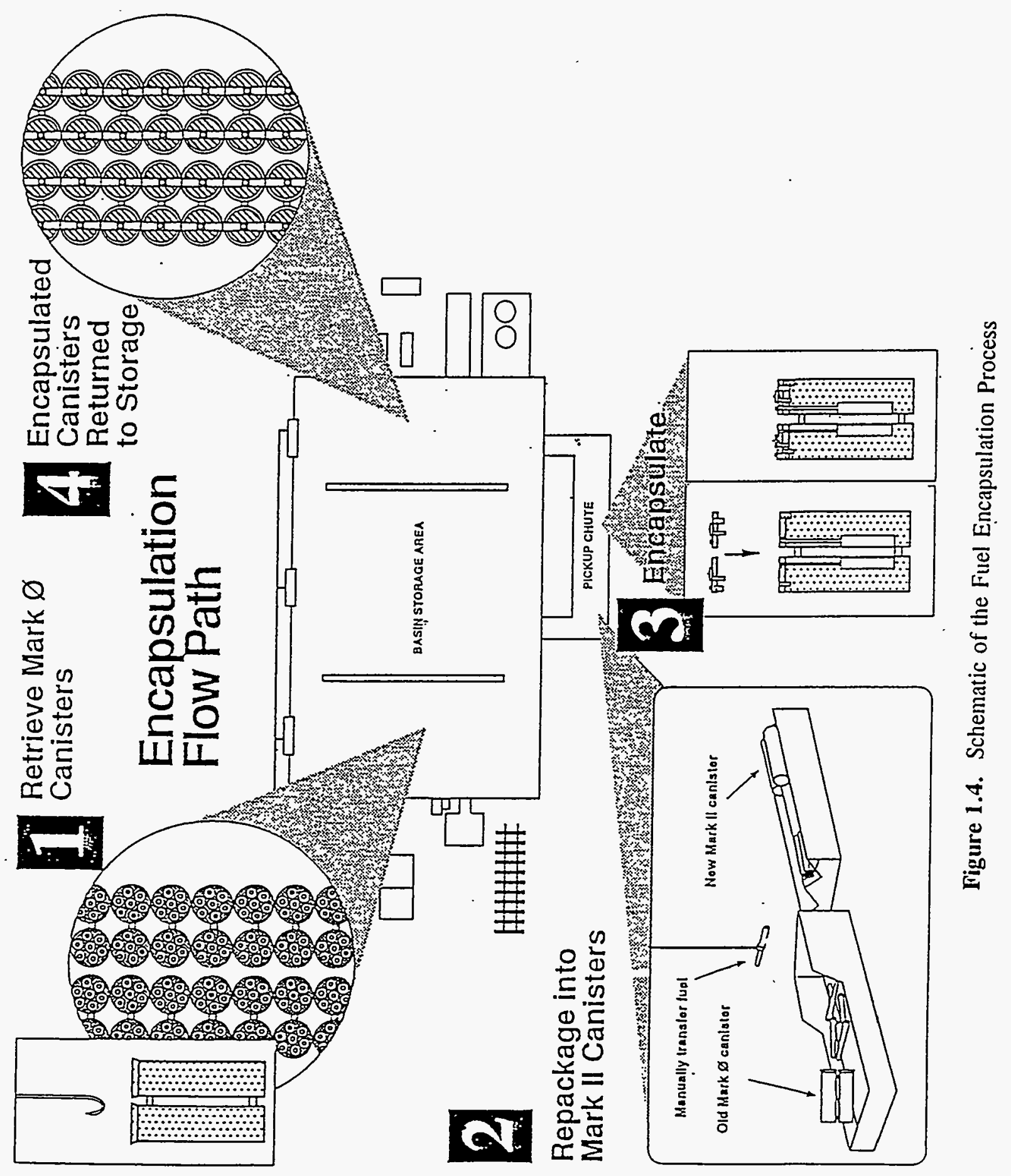

Rev. 2 


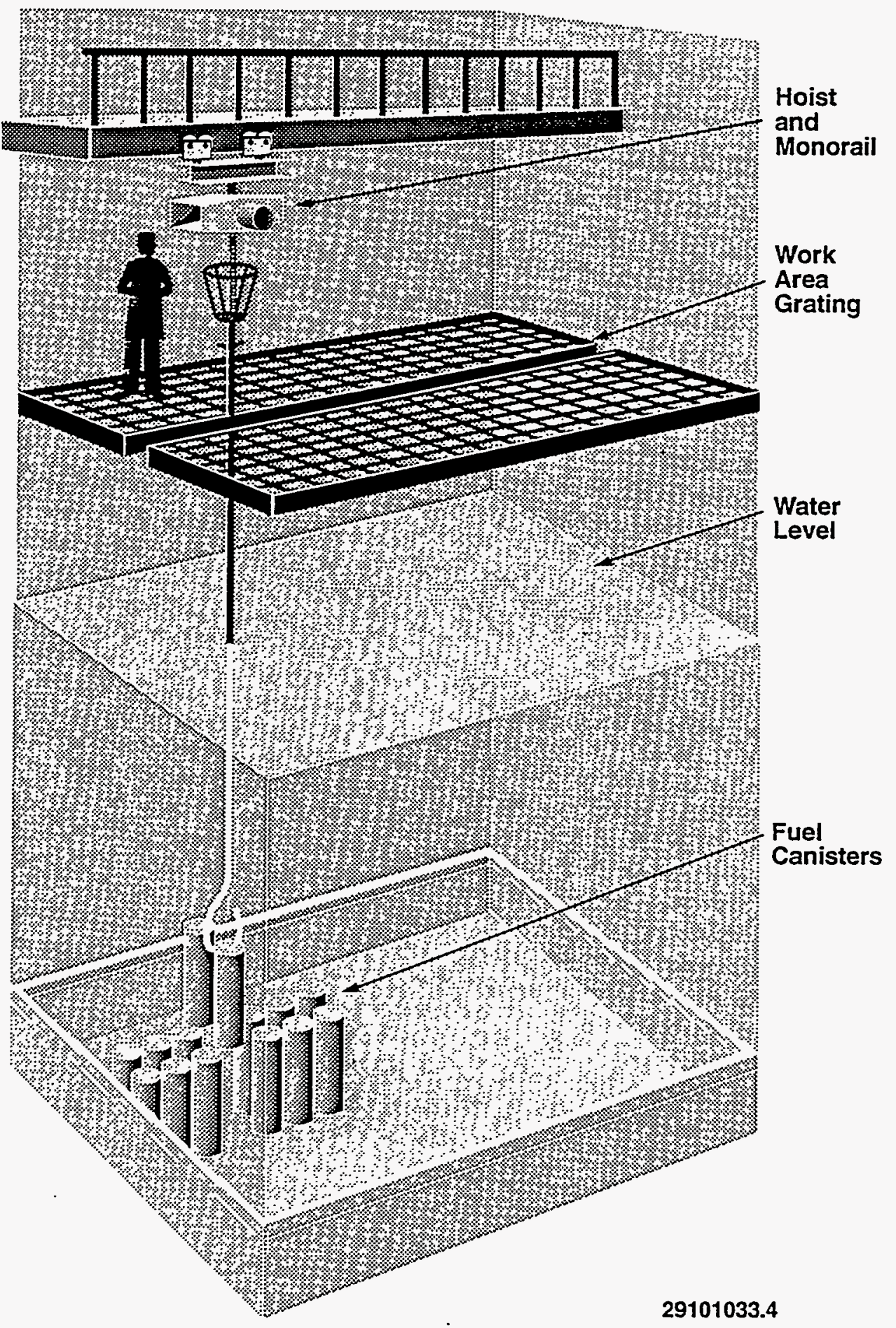

Figure 1.5. General Work Arrangement 


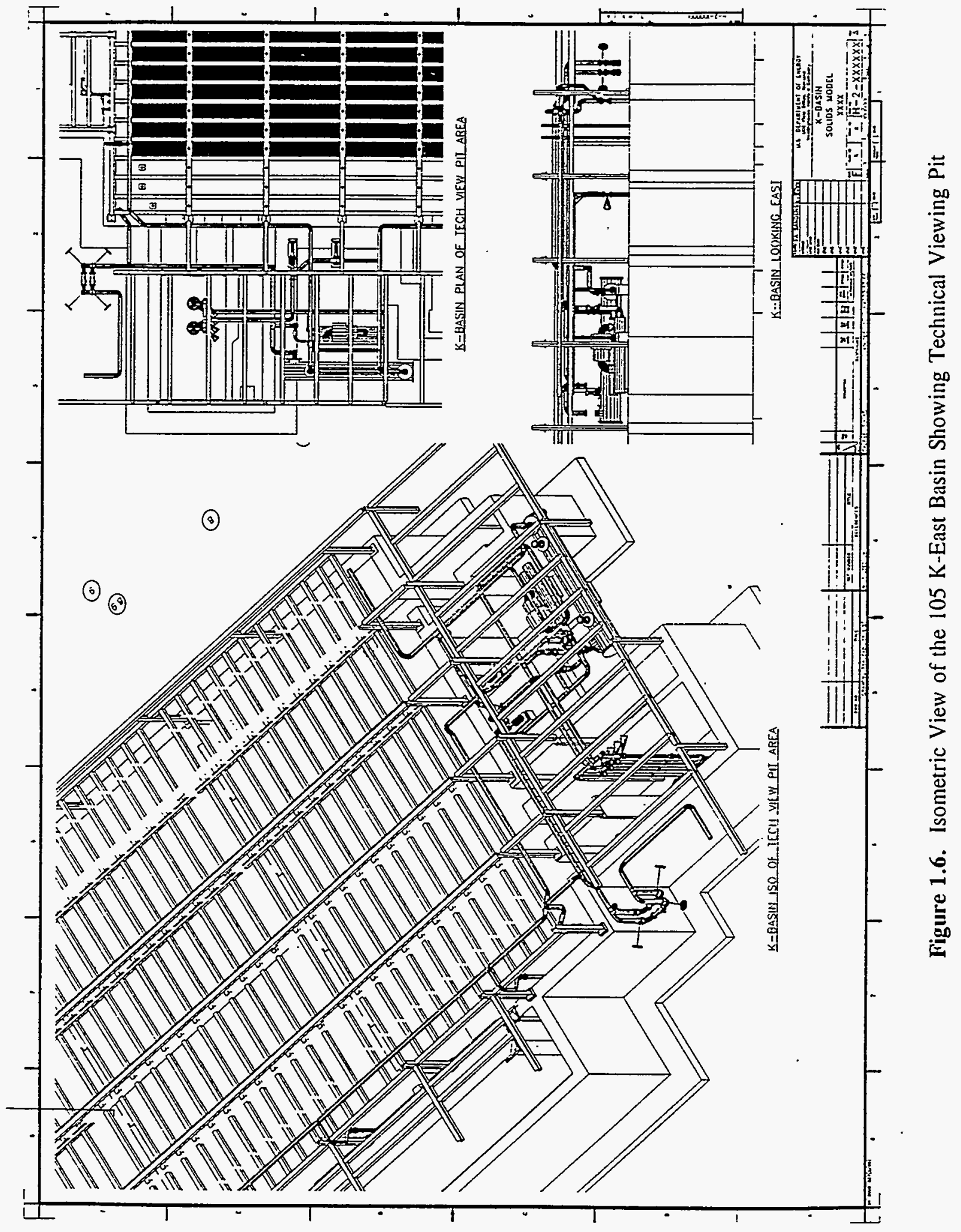

Rev. 2 


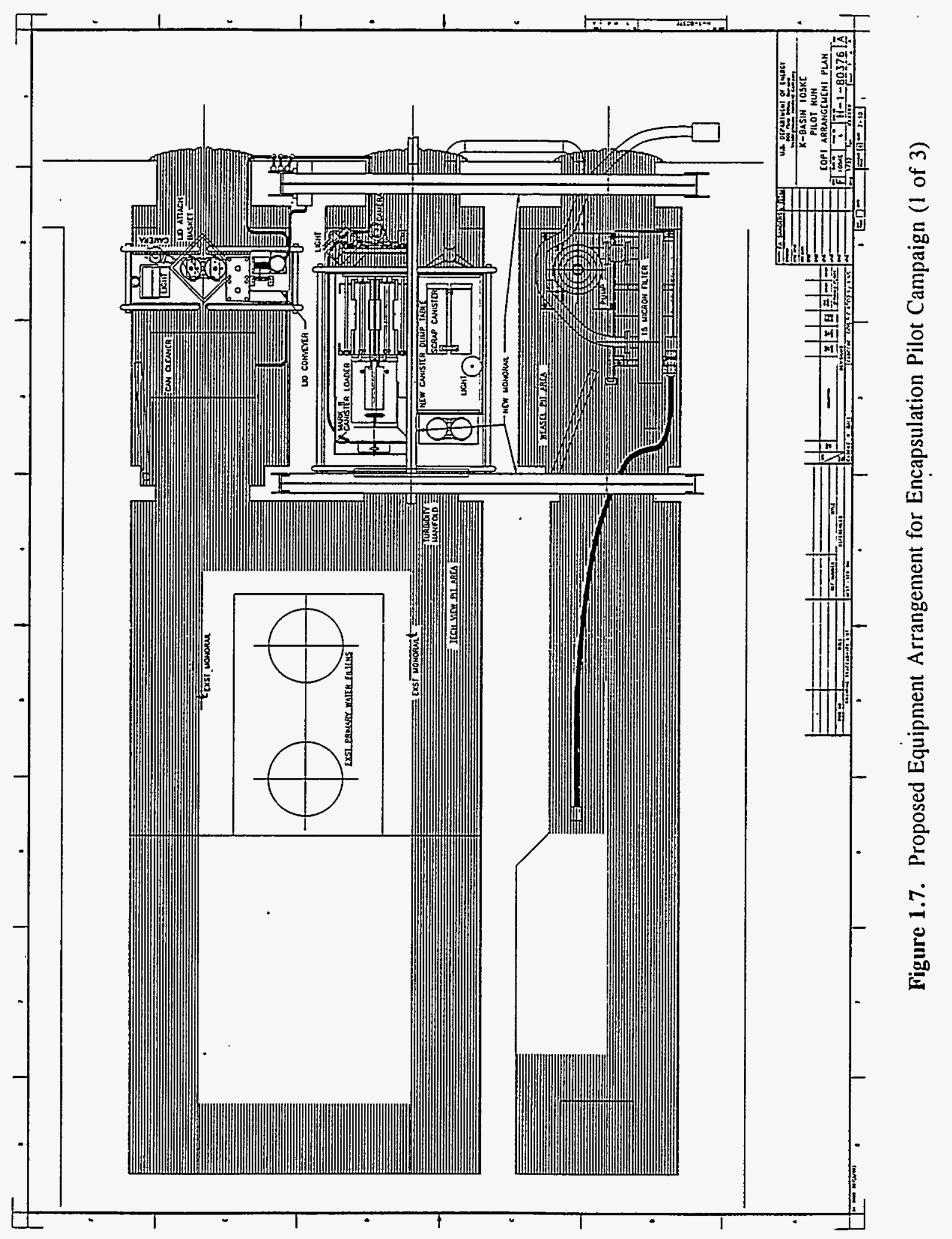




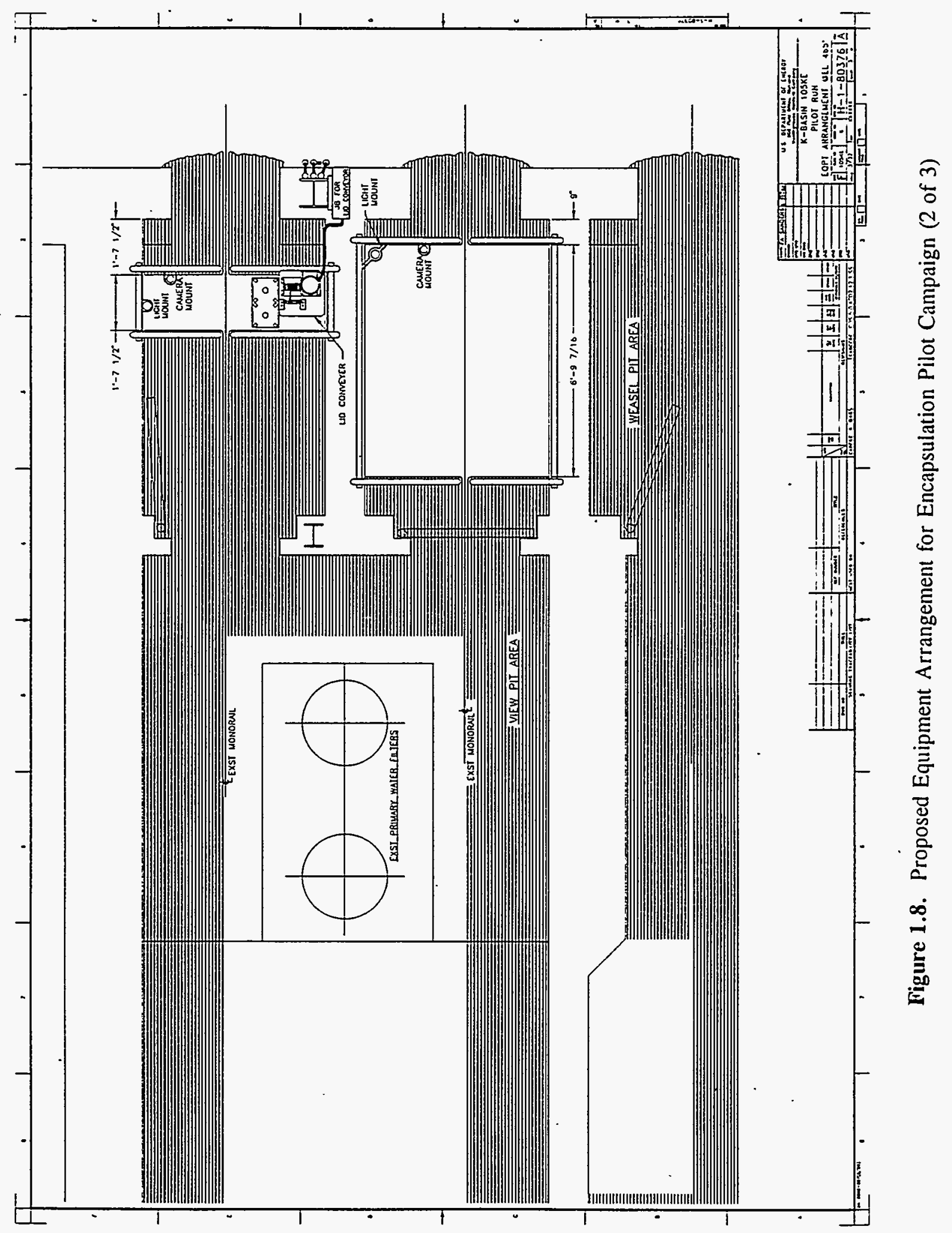

Rev. 2 


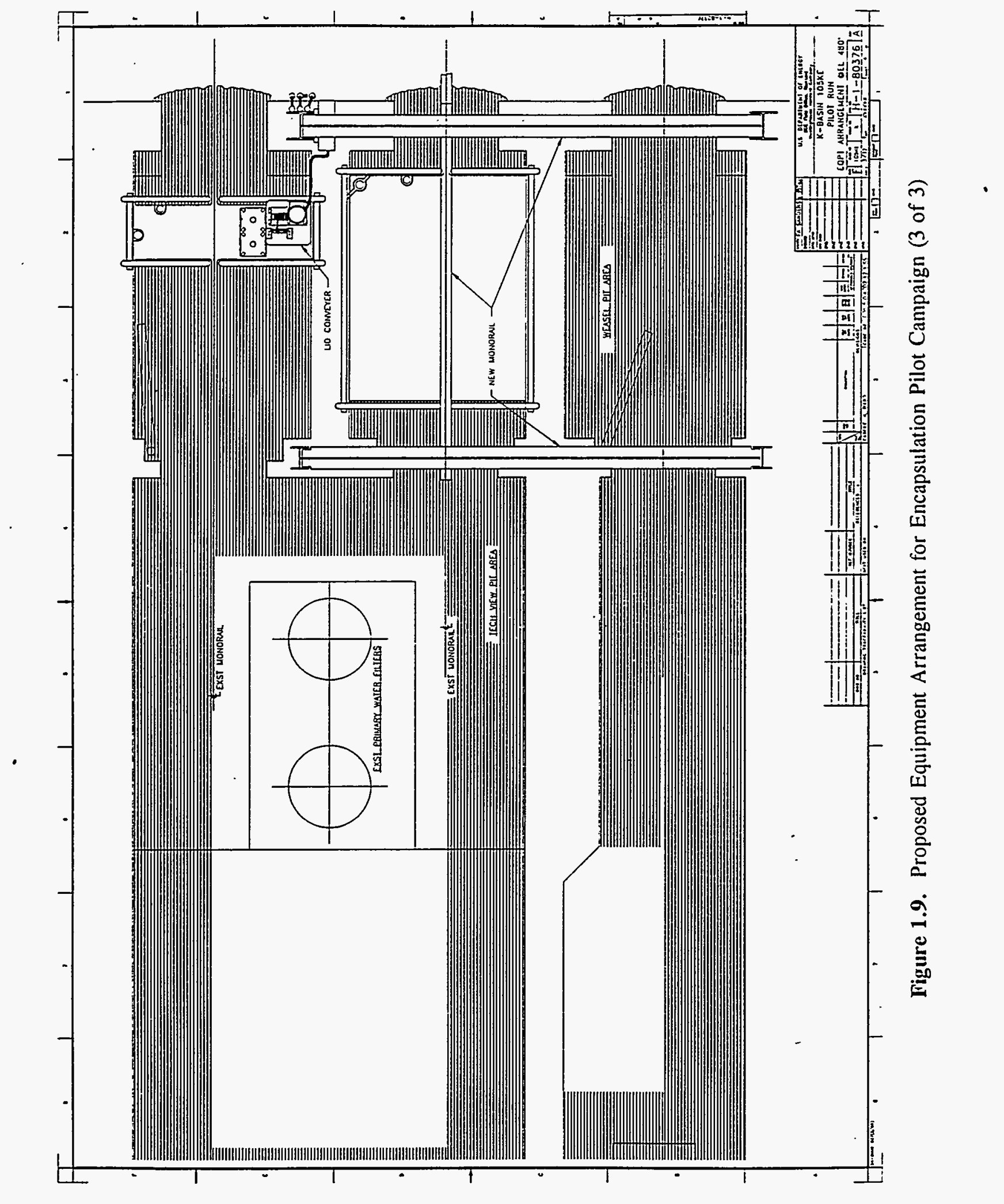




\subsection{Methods and Procedures}

This study started with a thorough review of both existing WHC policy, procedures, and practices for operations at the $105 \mathrm{KE}$ Fuel Storage Basin as well as the proposed encapsulation campaign activities. A document review was also conducted of WHC's Radiological Control Program, as well as the ALARA program and its implementation. A review of DOE requirements and Orders and other applicable federal guidance was performed to determine if current practices met applicable requirements. In addition to document reviews, numerous WHC staff were interviewed and facilities were toured.

It is important to note that the ALARA process implies an analysis of the expected benefits of an action versus the cost of such an action. In this study, however, it was not possible to perform a rigorous cost-benefit analysis, because of the short schedule and lack of cost data for many of the proposed actions. Therefore, the study focused on determining realistic dose rates, as well as alternatives for collective-dose reduction that would be reasonable and implementable within the previously established schedule for encapsulation.

\subsection{Guidance Documents Reviewed}

As an initial part of the $105 \mathrm{~K}$-East FSB study, an extensive review of DOE Orders, Regulations, and guidance documents was performed to determine all necessary requirements relating to ALARA. In addition, knowledge of the Westinghouse ALARA program was obtained by reviewing Westinghouse policies, procedures, and documents. The following documents were used to determine requirements and good practices necessary for an acceptable ALARA Program:.

Title 10 Code of Federal Regulations Part 835, "Occupational Radiation Protection, Final Rule," December 14, 1993

- DOE Order 5480.11, Radiation Protection for Occupational Workers

- Radiological Control Manual, DOE/EH-0256T, 1992

- Implementation Guide, Occupational ALARA Program, G-10 CFR 835/B2 -Rev.0, 1993

- Health Physics Manual of Good Practices for Reducing Radiation Exposures to As Low As Reasonably Achievable (ALARA), PNL-6577, 1988

- Optimization and Decision-Making in Radiological Protection, ICRP Publication 55, 1990

Limitation of Exposure to Ionizing Radiation, NCRP Report No. 116, 1993 
Guidelines for Radiological Protection at Nuclear Power Stations, INPO Report 91-014, 1991.

Additional documents and procedures used in this study can be found in Section 5.0, References.

\subsection{WHC Documents Reviewed}

To assess the adequacy of the Westinghouse ALARA program, the following documents were reviewed as they relate to the K-East Fuel Storage Basin Encapsulation campaign:

ALARA Program Manual, WHC-CM-4-11, April 1992

Cost/Benefit Analysis at Westinghouse Hanford Company, WHC-SA-1533-FP, R.L. Brown WHC, C.J. Stephan, ECOTEK, Inc., April 1992

Approval of $K$ Area Encapsulation ALARA Plan, WHC-SD-NR-PLN-007 Rev 0, prepared by W.M. Bricker, 1991

Canister Disposal Options Report (Draft), M.J. Langevin, November 1993

KE Fuel Storage Basin Activity Mapping in Support of Exposure Reduction, UNI-1697, D.B. Bechtold, April 1981

Environmental Assessment of $105-E$ and 105 -W Basins Fuel Encapsulation and Repackaging, 100-K Area, Hanford Site, Richland, Washington, DOE/EA-0535, June 1992.

Additional procedures were reviewed and are referred to in Sections 3.0 and 4.0 .

\subsection{Persons Contacted}

During this study, the following persons were contacted:

RF Creed
VL Hoefer
MK Kaviani
JE Kurtz
DK Lemke
JD Mathews
WJ Millsap
TJ Ruane
JP Schmidt
JE Truax

Advanced Engineer

Manager, K Basins Operations

Manager, 100 Area Facilities Health Physics

Health Physics Analyst, 100 Area Facilities Health Physics

Manager, $105 \mathrm{~K}$-West Basin

Assistant Manager, $\mathrm{K}$ Basins Operations

Principal Engineer, Engineering Analysis and Technology

Manager, K Basins Facilities

Manager, K Basins Engineering

Director, K Basins

Rev. 2 
In addition to the persons listed above, various operators, technicians, and other support personnel were contacted. 


\subsection{Results}

Details of the information obtained from document reviews, staff discussions, and facility tours are summarized below and provide the basis for the recommendations provided in Section 4.0.

\subsection{Policies, Programs, and Procedures}

The following is a brief description of the Westinghouse Radiological Program as it relates to ALARA. The ALARA program is also described and a brief evaluation made.

\subsubsection{Radiological Control Program}

As required by 10 CFR 835, "Occupational Radiation Protection," Subparts B, C, F, H, J, K, and $\mathrm{N}$, and as part of their radiation protection activities, WHC has established a program to maintain radiation levels "as low as reasonably achievable" (ALARA). Additionally, WHC must meet the requirements and recommendations for ALARA contained in the DOE Radiological Control Manual (RCM) (DOE 1992). The WHC Radiological Control Manual (WHC RCM) describes the radiological safety policy requirements for WHC and combines radiation protection criteria with the standards of the Hanford Site Radiological Control Manual (HSRCM). The radiation protection requirements in the WHC RCM should meet the applicable requirements of the DOE and other agencies.

\subsubsection{WHC's ALARA Program}

With the publication of 10 CFR 835 and its associated guidance, the need for an ALARA program has been reemphasized. As a result, WHC's ALARA program, as currently defined, is being revised. The program is based on WHC's ALARA Program Manual (WHC 1988), which covers policies, responsibilities and authorities, ALARA goals, and program implementation. Since this, along with the WHC RCM, is the current policy document, it was the basis for reviewing WHC's ALARA program. The WHC ALARA program reflects practices identified in Health Physics Manual of Good Practices for Reducing Radiation Exposure to Levels That Are As Low As Reasonably Achievable (ALARA) (PNL 1988). Additional sources of information on the WHC ALARA program included an ALARA Points-of-Contact List and a document entitled Westinghouse Hanford Company ALARA Program Overview.

The overall review of WHC's ALARA program, plus a review of the document entitled ALARA Plan for Repackaging and Fuel Encapsulation at $105 \mathrm{KE}$ Basin (Bricker 1991), provide the basis for the recommendations outlined in Section 4.1.

Although WHC's overall ALARA program was evaluated, this report focuses on two significant findings relevant to the encapsulation campaign. The first relates to the overall WHC ALARA program, and the second is specific to the $105 \mathrm{~K}$-East repackaging and fuel encapsulation campaign. 
The major concern with the current WHC ALARA program is the level of management review and involvement. The WHC RCM addresses senior management commitment, but WHC's current ALARA Program Manual and relevant procedures do not indicate that ALARA goals are reviewed and directed by the highest WHC management. Discussions with WHC staff reinforce this conclusion.

The HSRCM, which implements the requirements of DOE Order N5480.6 (DOE 1992), establishes a graded system of Administrative Control Levels (ACLs) to control worker doses. These ACLs, contained in Table 2-1 of the HSRCM, are reproduced in Table 3.1 below, along with the position titles of the corresponding responsible officials. Similarly, the WHC ALARA goals for the 105 K-East Repackaging and Fuel Encapsulation Program should have this level of management attention. The existing program plan for this effort assumes the operators will receive up to 1750 mrem/y. This assumption appears to be contrary to the philosophy established in the HSRCM. Such an annual total effective dose equivalent would require approval from the highest levels of WHC management.

Table 3.1. Administrative Control Levels and Cognizant Officials

\begin{tabular}{|c|l||}
\hline \multicolumn{2}{|c|}{ Maximum Total Effective Dose Equivalent (annual), mrem } \\
\hline \hline Administrative Control Level & Approval Required to Exceed This Level \\
\hline 500 & Level 3 line manager and Radiological Control Manager \\
\hline 750 & Level 2 line manager and Radiological Control Manager \\
\hline 1000 & President, WHC \\
\hline 2000 & $\begin{array}{l}\text { DOE Assistant Secretary for Environmental Restoration } \\
\text { and Waste Management }\end{array}$ \\
\hline
\end{tabular}

\subsection{Organization, Staffing, and Training}

The organization that will be responsible for the $105 \mathrm{~K}$-East Fuel Storage Basin and Encapsulation Project was reviewed, with special attention paid to whether the level of staffing is adequate to accomplish the task while maintaining doses ALARA. For this same reason, the training of the personnel was reviewed to determine that staff were adequately prepared to perform their tasks. 


\subsubsection{Organization}

WHC has recently completed an extensive reorganization to effectively manage disposition of spent nuclear fuels (SNF) at Hanford. The Director, Spent Nuclear Fuel Project, a Level 1 manager, reports to the President, WHC. The Director, K Basins, a Level 2 manager, is responsible for K Basins operations, engineering, maintenance, SNF management and disposition, facilities administration, and environmental compliance.

Radiological protection coverage is provided by the 100 Area Facilities Health Physics organization, which is matrixed to the Director, $\mathrm{K}$ Basins. This organization consists of a manager, five health physicists (HP Analysts), three shift managers, and 17 Health Physics Technicians (HPTs).

The current organization includes 24 operators. An additional 9 operators currently assigned to N-Reactor could be utilized for encapsulation work. The availability of these nine operators after July 1, 1994, is uncertain because of the transition of responsibility for N-Reactor from WHC to the Environmental Restoration Management Contractor (ERMC). Operations management has requested the addition of seven operators to the $\mathrm{K}$ Basins organization for a total of 31 operators. The labor agreement requires dose equalization between workers in a given job classification. Line management has the discretion to rotate workers on the basis of skill and experience

The proposed organization for the encapsulation campaign consists of two shifts Monday through Friday, with a third shift of operators to provide relief for training. Of the 24 operators presently assigned to the K Basins, 19 have been assigned there since before 1983 and have performed most of the fuel-handling evolutions involved in the encapsulation campaign.

Staffing levels for the encapsulation campaign have been based on various assumptions. The KE/KW Fuel Encapsulation Task and KE Basin Cleanup Task Management Plan (Larson 1993) assumes that operators will be authorized to receive up to $1500 \mathrm{mrem} / \mathrm{y}$. The ALARA Plan for Repackaging and Fuel Encapsulation at $105 \mathrm{KE}$ Basin (Bricker 1991) assumed an annual dose authorization of 2000 mrem that would be controlled to 1750 mrem.

\subsubsection{Training and Qualification}

A training program for operators involved in the fuel encapsulation campaign has been developed. This three-week program consists of two weeks of classroom instruction followed by one week of on-the-job training (OJT). A qualification record is used to document trainee progress and the training program culminates with an evaluation by line management. Separate ALARA training is not provided; however, dose reduction techniques are included in the OJT for individual tasks.

Requalification is accomplished over a two-year cycle. The first class started March 28, 1994. This training also incorporates routine surveillances. This training is limited to operators; HPTs are not included in the specific training program for encapsulation. 
Replacement HPTs require 13 to 16 weeks of Site training followed by approximately six months of OJT to be fully qualified for assignment to the $\mathrm{K}$ Basins. Health Physics Technicians are also required to participate in a biennial requalification program.

\subsection{ALARA Program Implementation}

Collective dose history for the past two years was reviewed to evaluate the implementation of the ALARA program as it relates to the $105 \mathrm{~K}$-East Fuel Storage Basin and Encapsulation program.

\subsubsection{Collective Dose History}

Collective dose data since 1992 are available from the Westinghouse Radiation Area Management (WRAM) system. Paper records for prior years are in archival storage and were not retrieved as part of this study. During 1992 and 1993, activities were limited to maintenance and surveillance. Table 3.2 summarizes these data for 1992 and 1993.

Table 3.2. Collective Doses, 1992-1993

\begin{tabular}{||c|c|c|c|c||}
\hline & \multicolumn{2}{|c|}{ K-West Basin } & \multicolumn{2}{c|}{ K-East Basin } \\
\hline \hline Year & mrem $^{(\mathrm{a})}$ & Entries & mrem $^{(\mathrm{a})}$ & Entries \\
\hline 1992 & 250 & 751 & 19,699 & 3,764 \\
\hline 1993 & 1,140 & 167 & 23,880 & 6,271 \\
\hline
\end{tabular}

(a) These values are compiled from self-reading pocket dosimeter readings. Actual values may vary $\pm 10 \%$.

Activities during the first three months of 1994 have incurred approximately 4 person-rems, almost entirely at $105 \mathrm{~K}$-East.

\subsubsection{Collective Dose Projections and Goals}

A number of studies have been performed by WHC to evaluate the collective dose impact of $105 \mathrm{~K}$-East operations, the encapsulation campaign, and the subsequent cleanup. The $K E / K W$ Fuel Encapsulation Task and KE Basin Cleanup Task Management Plan (Larson 1993) evaluates three scenarios for encapsulation and basin cleanup:

Option 1: Basin cleanup (excluding canister disposal activities) will occur after fuel encapsulation has been completed - 157 person-rems.

Rev. 2 
Option 2: $\quad$ Basin cleanup (including canister disposal activities) will occur concurrently with fuel encapsulation - 169 person-rems.

Option 3: $\quad$ Basin cleanup (including canister disposal activities) will occur before the start of fuel encapsulation - 188 person-rems.

Each of these options involves a number of assumptions:

Basin sludge will be consolidated into the K-East Basin's weasel pit.

Encapsulation will be performed using two shifts working five days per week.

Source-reduction actions (coating the basin walls, raising water level, and using temporary shielding) would reduce general area dose rates by a factor of two to three.

In this plan, fuel encapsulation is projected to require 102 person-rems over a period of 24 months. Canister disposal is assumed to cost 29 person-rems and require seven months to complete. Actions required to raise the basin water level are projected to cost 9 person-rems. No completion time is reported, however. This plan also states that approximately $70 \%$ of the encapsulation activities are assumed to occur in the discharge chute area.

The ALARA Plan for Repackaging and Fuel Encapsulation at 105 KE Basin (Bricker 1991), prepared in accordance with the requirements of the ALARA Program Manual (WHC 1992), presents a more detailed analysis of the collective dose anticipated for this project. Section 3.6 of the abovecited report contains collective dose goals for operators, supervisors, maintenance personnel, and HPTs; however, it makes no distinction between a collective dose estimate and a collective dose goal. This is at variance with good health physics practice. Approximately 140.2 person-rem goal will be spent on encapsulation, or approximately 24.7 person-mrem per canister. This study assumes that the production rate will be 16 canisters per day. Using these goals and assumptions, line management could expect workers to incur approximately 400 person-mrem per day for a period of 45 weeks.

ALARA goals for 100-K for calendar year 1994 have been established and communicated to line management by a memorandum from J.E. Truax. ${ }^{(a)}$ The goal for encapsulation is stated as a $10 \%$ reduction of the 128 person-rem projected in the Task Management Plan (Larson 1993).

(a) Memorandum to J.F. Dickman from J.E. Truax, "Calendar Year 1994 ALARA Goals for 100-K," dated November 4, 1993. 


\subsection{Radiological Source Term}

WHC and its predecessors have completed numerous measurements and studies of the radiological source term in the $105 \mathrm{~K}$-East Basin (Bricker 1981). As part of this evaluation, PNL staff have reviewed these studies and developed a comprehensive radiological model of the $105 \mathrm{~K}$-East Basin. This model is used to evaluate the effectiveness of various source-reduction alternatives.

\subsubsection{Fuel Storage Basin Water}

Water quality in the $105 \mathrm{~K}$-East Basin is maintained through the use of a $0.5-\mu \mathrm{m}$ cartridge filter, a sand filter, ion-exchange columns (IXC), and ion exchange modules (IXM). Radionuclide analysis of the basin water is performed weekly. Normally, one IXM is in service. Because of concerns about the high dose rates associated with the replacement of IXCs, they are maintained as a backup to the IXMs. While it is possible to further reduce FSB activity concentrations by operation of a second IXM, the $\mathrm{pH}$ reduction in the effluent causes problems in maintaining basin water $\mathrm{pH}$ within operational safety requirement (OSR) limits.

The principal gamma-emitting radionuclide in the $105 \mathrm{~K}$-East FSB water is ${ }^{137} \mathrm{Cs}$, at a nominal concentration of $1 \mu \mathrm{Ci} / \mathrm{L}$ to $5 \mu \mathrm{Ci} / \mathrm{L}(40 \mathrm{kBq} / \mathrm{L}$ to $200 \mathrm{kBq} / \mathrm{L})$. The recent addition of on-site gamma-ray analysis capability for basin water samples has significantly reduced the large activity excursions (as high as $24 \mu \mathrm{Ci} / \mathrm{L}$ [960 kBq/L] ${ }^{137} \mathrm{Cs}$ ) associated with the release of activity from depleted ion exchange modules. The analyses performed in this study assume a basin activity concentration of $5 \mu \mathrm{Ci} / \mathrm{L}(200 \mathrm{kBq} / \mathrm{L})$.

Strontium-90 concentrations are on the order of $0.5 \mu \mathrm{Ci} / \mathrm{L}$ to $4 \mu \mathrm{Ci} / \mathrm{L}(20 \mathrm{kBq} / \mathrm{L}$ to $160 \mathrm{kBq} / \mathrm{L}$ ) and generally follow changes in ${ }^{137} \mathrm{Cs}$ concentrations. Plutonium- 239 concentrations are lower, approximately $0.01 \mu \mathrm{Ci} / \mathrm{L}$ to $0.04 \mu \mathrm{Ci} / \mathrm{L}(400 \mathrm{~Bq} / \mathrm{L}$ to $1600 \mathrm{~Bq} / \mathrm{L})$.

To control air emissions from the $105 \mathrm{~K}$-Basins, two action levels are in effect. Action Level 1, presently set by the Washington Department of Ecology (WDOE) at $15 \mu \mathrm{Ci} / \mathrm{L}(800 \mathrm{kBq} / \mathrm{L})$, requires that action be taken to reduce activity concentration in the FSB water. Action Level 2, presently set at $30 \mu \mathrm{Ci} / \mathrm{L}(1600 \mathrm{kBq} / \mathrm{L})$, requires that all activities in the basin cease.

\subsubsection{Contaminated Concrete Surfaces}

With the exception of the discharge chute (DC) area, the $105 \mathrm{~K}$-East FSB concrete surfaces are unpainted. A visual inspection of the Technical Viewing Pit revealed that the concrete surfaces appear to be painted. Some degradation of the concrete has resulted in the formation of a friable surface layer several millimeters thick. Wetted portions of the unpainted concrete walls have absorbed significant quantities of ${ }^{137} \mathrm{Cs}$ from the basin water. In 1981, the operating contractor initiated a study to characterize the extent of contamination of the concrete (Bechtold 1981). This study involved sampling of the friable layer above and below the basin water level; radiation and contamination surveys, including gamma spectrometry; and limited core sampling. 
The results of the 1981 study indicate that ${ }^{137} \mathrm{Cs}$ contamination is the overwhelming contributor to dose rates in the FSB area. The ${ }^{137} \mathrm{Cs}$ has been absorbed within the friable layer of the concrete with concentrations between $5 \mu \mathrm{Ci} / \mathrm{cm}^{2}$ and $15 \mu \mathrm{Ci} / \mathrm{cm}^{2}\left(190 \mathrm{kBq} / \mathrm{cm}^{2}\right.$ to $\left.560 \mathrm{kBq} / \mathrm{cm}^{2}\right)$. Some contamination penetrated to a depth of $9 \mathrm{~mm}(0.35 \mathrm{in})$ into the concrete. For purposes of this study, a uniform surface contamination of $10 \mu \mathrm{Ci} / \mathrm{cm}^{2}\left(400 \mathrm{kBq} / \mathrm{cm}^{2}\right)$ with negligible self-absorption in the friable layer of concrete was assumed.

\subsubsection{Fuel Storage Basin Water Systems}

Two separate, but related, systems maintain FSB water quality and remove decay heat. The FSB cooling water system consists of three inlet lines (one drawing from the south end of each FSB bay), a recirculating pump, two $5-\mu \mathrm{m}$ cartridge filters, a chiller, and a return line to each FSB bay. This system operates at a design flow of 500 gallons per minute $(31.5 \mathrm{~L} / \mathrm{s})$ and also supplies the IXCs if they are placed in service. The FSB water-cleaning system consists of skimmers, a skimmer pump, a sand filter, and return piping. This system operates at a design flow rate of 400 gallons per minute $(25.2 \mathrm{~L} / \mathrm{s})$. The skimmer pump supplies the IXMs. The general system configuration is shown in Figure 3.3.

The return piping of the FSB's cooling water system consists of a header (line designation 8 " BW-A-12) constructed of 8-in (20-cm) diameter Schedule 40 carbon steel piping with 6-in (15-cm) diameter branch lines (designated $6^{\prime} \mathrm{BW}-\mathrm{A}-13,14$, and 15) supplying return flow to each bay. The header is approximately $3.2 \mathrm{~m}(10.3 \mathrm{ft})$ above the grating, and the return lines extend from the header to below the surface of the water. Each branch line has a flow element and isolation valve.

Because of the presence of air-saturated water at low flow velocities, general corrosion has occurred in the basin's cooling water system piping and other components. The accumulation of radioactive contamination in the corrosion layer of this piping has resulted in high dose rates in the vicinity of the basin's cooling water system piping $(60 \mathrm{mrem} / \mathrm{h}$ to $110 \mathrm{mrem} / \mathrm{h}$ at or near contact with the piping.) Some temporary shielding has been used; however, a significant portion of 8" BW-A-12 remains unshielded. While some benefit could be realized through the use of additional temporary shielding, a reduction in the piping's radiological source term is preferable.

\subsubsection{Dose Model}

A model of the $105 \mathrm{~K}$-East FSB and discharge chute was developed using the gamma-dose computer code WISE (Reece et al. 1989). The primary source terms that were modeled included the basin water, the bathtub ring at the water level around the basin, the return water lines, and the primary water header. Structures that were modeled included the basin walls, the two primary support walls inside the basin, and the discharge chute platform. A large lead shield on the west side of the platform was also modeled. When doses from the return lines were modeled, the lead shielding and the west support pylon surrounding the return line near the discharge chute platform were included. The effect of placing a water shield on the discharge chute platform was also modeled. The grating above the basin was not modeled because it does not provide a significant amount of 
shielding. A schematic representation of the basin is shown in Figure 3.1, and a schematic drawing of the piping is shown in Figure 3.2. The model used to evaluate doses to personnel from encapsulation activities in the Technical Viewing Pit area is shown in Figure 3.3. Similarly, the sludge layer and the fuel at the bottom of the basin were not modeled because the dose contribution from these sources was not significant.

The basin water was assumed to be uniformly contaminated with ${ }^{137} \mathrm{Cs}$ at a concentration of $5 \mu \mathrm{Ci} / \mathrm{L}(200 \mathrm{kBq} / \mathrm{L})$. The concrete surfaces around the circumference of the basin were assumed to be uniformly contaminated with ${ }^{137} \mathrm{Cs}$ at a concentration of $10 \mu \mathrm{Ci} / \mathrm{cm}^{2}\left(400 \mathrm{kBq} / \mathrm{cm}^{2}\right)$. The nominal depth of the water was modeled as $16 \mathrm{ft}(4.9 \mathrm{~m})$. It was assumed that the "bathtub ring" layer extended from a depth of $13 \mathrm{ft}(3.9 \mathrm{~m})$ above the bottom of the basin to a height of $16.2 \mathrm{ft}(4.94 \mathrm{~m})$ above the bottom of the basin. The concentration of contamination in the return lines was determined based on RO-2 readings taken in contact with the outside of the return lines. WISE was used to back-calculate the activity concentration of ${ }^{137} \mathrm{Cs}$ in the return lines near the discharge chute platform. For the east return line, the curie concentration was determined to be $2 \mu \mathrm{Ci} / \mathrm{cm}^{2}\left(74 \mathrm{kBq} / \mathrm{cm}^{2}\right)$, and the concentration was determined to be $1.7 \mu \mathrm{Ci} / \mathrm{cm}^{2}\left(63 \mathrm{kBq} / \mathrm{cm}^{2}\right)$ for the central return line. No measurements were made on the primary header, for which a concentration of $2 \mu \mathrm{Ci} / \mathrm{cm}^{2}$ $\left(74 \mathrm{kBq} / \mathrm{cm}^{2}\right)$ was assumed. Doses from the west return line were not significant at the locations of the calculations.

Dose points in the Technical Viewing Pit (TVP) were also modeled. The water contamination level in the TVP was assumed to be the same as that in the main basin. Measurements performed using a Xetex Telescan extendable exposure rate instrument indicated that no bathtub ring exists in the TVP, so this source was not included in the calculations. In fact, measured dose rates at the surface of the water were slightly lower than at the grating level, indicating that the dominant radiation sources in the TVP are above the grating level. A large amount of piping in the area of the TVP, some of which had contact dose rates of $90 \mathrm{mR} / \mathrm{h}$, contributes a significant amount to personnel dose in the TVP. The source term developed for each of the pipes was based on the Xetex measurements, and the inner surfaces of the pipes were assumed to be uniformly contaminated.

Doses were calculated at three points above the TVP, and at one point above the main basin approximately $50 \mathrm{~cm}$ from the TVP. The latter point was chosen because this location seems to be a natural location for workers to congregate between tasks. The height of each point was $3 \mathrm{ft}(0.9 \mathrm{~m})$ above the grating. The three points chosen above the TVP included a point above the center of the pool east of gate \#1, a point above the support wall between gate \#1 and gate \#2, and a point below the lines 8" BW-A-5 and 8" BW-A-11. The results of the calculations are presented in Section 3.6.4.

Doses were calculated at eight representative points in the basin. The height of each point was $3 \mathrm{ft}(0.9 \mathrm{~m})$ above the grating. One point was centrally located over the basin and away from the support walls. A second point above the basin was chosen near the eastern support wall. The remaining six points were chosen on the discharge chute platform in the area where the encapsulation work will be performed. Three points were chosen on the grating above the discharge chute $1 \mathrm{ft}$ $(0.3 \mathrm{~m})$ south of the platform, and were located on the east side, the middle, and the west side. A 
5-in (130-m) riser on the grating was included for these points. The final three points were chosen over the middle of the platform on the east side, the middle, and the west side.

The primary purpose of the model was to estimate the change in ambient dose rate caused by changes in the basin's water level. Water levels modeled included $-16 \mathrm{in}$. $(40.6 \mathrm{~cm}),-8 \mathrm{in}$.

$(20.3 \mathrm{~cm}),-4$ in. $(-10.2 \mathrm{~cm}), 0$ in. $(0 \mathrm{~cm}),+8$ in. $(20.3 \mathrm{~cm}),+14$ in. $(35.6 \mathrm{~cm})$, and +20 in. $(90.8 \mathrm{~cm})$, where 0 in. $(0 \mathrm{~cm})$ corresponds to a water level of $16 \mathrm{ft}(1.8 \mathrm{~m})$. An additional calculation was performed to determine the effect of adding a 16-in $(40.6-\mathrm{cm})$-thick, $6-\mathrm{ft}(1.8 \mathrm{~cm})$ -tall water shield along the back of the platform with the water level remaining at $16 \mathrm{ft}(4.9 \mathrm{~m})$. The secondary purpose of the model was to determine the relative intensity of the three sources, thus identifying prime targets for remediation. Results of the calculations are presented and discussed in Section 4.0.

\subsection{Current Operations}

Studies were performed for various tasks at the $105 \mathrm{~K}$-East Basin. Walk-throughs of these tasks were performed with cognizant plant personnel at the $105 \mathrm{~K}$-West Basin. Similarities and differences in layout and tasks were discussed, and a time-motion study was performed. Several aspects of the tasks were discussed in detail, including

- $\quad$ problems encountered in past operations

- $\quad$ projected hold points

- $\quad$ anticipated changes in practice from current procedural requirements

- $\quad$ potential problems in future operations

- $\quad$ anticipated "engineering fixes."

\subsubsection{Spent Cartridge Filter Replacement}

A time-motion study was completed for this task by conducting interviews and walk-throughs with personnel who were familiar and experienced with the proposed procedures. Plant personnel indicated that changes to the procedure were anticipated, and the changes were included during the time-motion study. Several considerations were identified as having a significant influence on personnel exposure, and these considerations led to the recommendations presented in Section 4.5.1.

Plant personnel indicated that significant delays are encountered when the cartridge housing lid is connected to the housing because of difficulties aligning the swing bolts. The use of removable guide pins would alleviate the alignment problems.

The hoist hook that is used to lift the cartridge housing lid is not matched to the lifting ring on the lid. Replacing the hook with a hook that is fitted to the lifting ring will reduce the time required to remove the lid, thereby reducing the time required to perform the filter replacement. 
- A chain lanyard, which is used to remove the lid of the cartridge housing and place it in temporary storage during cartridge replacement, is currently bolted to a rail when it is not in use. Because the operation requires the use of protective gloves that hinder handling of the bolt, replacing the bolt with an adequate quick-release hook would simplify the procedure.

Weighing the cartridge is a multi-step process that requires detaching the canister before and after attaching the dynamometer. Weighing the canister would be greatly simplified and the time required would be considerably reduced if the dynamometer could be left in place on the hoist throughout the canister-replacement procedure.

The current method of wrapping the replaced cartridge for contamination control purposes is to use a plastic bag. During this procedure, personnel must come nearly in contact with the

filter. Replacing the plastic bag with a rigid plastic container made specifically for containment of the filter would significantly reduce the time spent close to the filter and the likelihood of spreading contamination.

Plant personnel indicated that the rubber gasket that prevents unfiltered water from bypassing the filter cartridge occasionally becomes detached during removal or installation of the filter. Retrieval of the gasket is time-consuming, especially if the gasket becomes detached during installation of a new filter cartridge. Using a stronger adhesive to attach the gasket to a new cartridge prior to its installation would greatly reduce the likelihood of this event.

Recommendations based on these considerations are presented in Section 4.5.1.

\subsubsection{Ion Exchange Column Replacement}

The greatest inefficiencies in the process occur during manipulaton of parts while installing the column inlet, outlet, and vent connection plugs. These inefficiencies were reported to be the result of worn or inadequately designed tools used to thread the plugs into the column. The inlet and outlet plugs are often dropped off the end of the tool, and the plugs are difficult to align properly to thread the components into the expended column. When the plugs drop off the tool, they must be retrieved by use of remote tools through the top of the cell. This delay results in additional exposure to personnel in the general area and additional time with the column interior exposed to the air. By improving the tools used to install the plugs and maintaining an available supply of extra plugs, the amount of time spent in close proximity to the used filter is decreased.

Plant personnel indicated that the lower column connections do not line up when the column is placed on the floor of the cell. To reach the connection with the tools, the operators use the crane to lift the column and align it with the access port. Steps should be taken to ensure that the column connections are aligned with the access port when the filters are installed.

When the column is prepared for shipment, it is placed into a drum lined with a large plastic bag into which a large steel guide tube has been placed. When the column comes to rest in the

Rev. 2 
bottom of the drum, the column is unrigged, the guide tube is removed, and the plastic bag is wrapped up at the top of the column. This requires personnel to approach the unshielded column again in order to wrap it. In addition, the column has sufficient weight, about $800 \mathrm{lb}(364 \mathrm{Kg})$, to break through the plastic bag when coming to rest on the bottom of the bag. Replacing the plastic bag with a rigid plastic container made specifically for containment of the filter would reduce the time spent close to the filter and the likelihood of spreading contamination.

\subsubsection{Ion Exchange Module Operation and Replacement}

No walk-through was performed for this task, but Procedures 59-07-23, 59-07-48, and 59-07-53 were reviewed and the area was toured to determine if any efficiencies could be attained either in time, through waste minimization, or in exposure. No additional labor or dose savings were identified.

\subsubsection{Sand Filter Sampling}

The task was analyzed relative to those subtasks performed in the basin/pool area, from preparation of the area to replacement of the tank lid. A review of the task indicates that to obtain a small (approximately $30 \mathrm{~g}$ ) sample requires removal and reinstallation of several large components. The configuration of the vent piping as it enters the top of the shield plug appears to be such that it enters the top of the tank, on the vertical and unobstructed. Neither an examination of plant diagrams nor discussions with plant personnel could confirm the details of the vent line's internal construction.

The purpose of the sample is to determine plutonium loading in the filter. In 1992 and 1993, plutonium activity in the pool ranged from about $0.02 \mu \mathrm{Ci} / \mathrm{L}(740 \mathrm{~Bq} / \mathrm{L})$ to about $0.13 \mu \mathrm{Ci} / \mathrm{L}$ $(4810 \mathrm{~Bq} / \mathrm{L})$, being particularly high during periods when the ion exchange modules and columns were exhausted. When the encapsulation campaign starts, movement of fuel through the basin is likely to create far greater quantities of dissolved or suspended plutonium, resulting in more rapid loading of the sand filter and greater frequency of sampling.

The current procedural requirements for sampling appear to involve significantly greater effort and time, and thus greater exposure, than would be the case if sampling through the vent line could be found to be feasible.

\subsection{Encapsulation Campaign}

Studies were performed for the encapsulation campaign task at the $105 \mathrm{~K}$-East Basin. Walkthroughs of the campaign were performed with cognizant personnel at both $105 \mathrm{~K}$-East and $105 \mathrm{~K}$-West Basins. The proposed encapsulation and canister disposal methods were discussed, and a time-motion study was completed to estimate the collective dose for the encapsulation campaign. 


\subsubsection{Proposed Encapsulation Method}

The proposed encapsulation method uses an assembly-line type procedure to remove fuel from Mark 0 or Mark I canisters to Mark II canisters. Encapsulation, which will require five people to perform, will occur in the discharge chute located south of the storage basin. One person will be dedicated to moving the fuel in old canisters to the discharge chute and returning the encapsulated fuel to the storage basin. Two other people will perform the encapsulation, with one person dedicated to handling of the fuel and the other person dedicated to performing a quality control check of the new canisters and lids and recording data. A fourth person (a supervisor) will be required to verify the process at various times, but will not likely be present during the entire encapsulation process. Finally, a health physics technician (HPT) must be present at all times to monitor dose rates and to survey for contamination.

Transfer and encapsulation of the fuel will use the following Westinghouse Procedures:

\begin{tabular}{|c|c|c|c|}
\hline $\begin{array}{l}\text { Proc. } \\
\text { No. }\end{array}$ & Title & $\begin{array}{l}\text { Rev. } \\
\text { No. }\end{array}$ & $\begin{array}{l}\text { MMDDYY } \\
\text { Approved }\end{array}$ \\
\hline $59-07-42$ & $\begin{array}{l}\text { Repackage and Encapsulate N-Reactor Fuel at } 105 \mathrm{~K} \text {-East } \\
\text { Basin }\end{array}$ & NEW & $04 / 05 / 93$ \\
\hline $59-07-45$ & Clean and Crush Canisters Stored in $105 \mathrm{~K}$-East Basin & NEW & $02 / 23 / 93$ \\
\hline $59 / 60-07-35$ & $\begin{array}{l}\text { Remove Crushed MKI and MKII Canisters from } \\
105 \text { K-East/K-West Storage Basins }\end{array}$ & 2 & $01 / 28 / 93$ \\
\hline $59 / 60-46-1$ & $\begin{array}{l}\text { Package Low-Level Solid Radioactive Waste in } 4 \times 4 \times 8 \\
\text { Boxes }\end{array}$ & NEW & $06 / 16 / 93$ \\
\hline
\end{tabular}

In the original encapsulation plan, the first step was to transfer fuel to the discharge chute. This was to be accomplished using a hoist, chains, stiffbacks, and rails. After being brought into the discharge chute, the fuel canister would have been moved to the packaging table and the fuel spilled onto the table. The empty canister was then to have been transported to temporary storage or to the canister cleaner. By use of tongs, the fuel would then be manually transported into a packager. When the packager was full, i.e., when 14 pieces of fuel were loaded into the packager, the fuel would then be loaded into a Mark II container using a plunger mechanism. The number and lengths of the fuel pieces would be recorded, and the new canister transported to the encapsulation station. Under the revised plan, those portions of encapsulation originally planned to be done in the discharge chute will be completed in the Technical Viewing Pit.

Once the new canister arrives at the encapsulation station, the contents are to be videotaped and the key number of the fuel recorded. Canister covers are then installed and the canister is purged with nitrogen and injected with a corrosion inhibitor. The encapsulated canister is then weighed, videotaped, and replaced in a new location in the storage basin. 


\subsubsection{Canister Disposal Alternatives}

Two options have been identified for disposing of the open top canisters. The first option is to clean and crush the old canisters and place them in a plastic-lined box for burial. The second option, for which no procedures currently exist, is to clean the canisters, assay them to determine the amount of residual fuel, and send them to a smelting operation either on-site or off-site. The smelting operation would allow the recovery of a portion of the metal that composes the canister.

The procedure for cleaning and crushing the old canisters is to first load a canister into the automated cleaner by means of rope hooks and pole hooks. When the cleaning is completed, the canister is moved by rope hooks and pole hooks to the crushing station. After crushing, which takes approximately $7 \mathrm{~min}$, the crushed canister is placed in a fuel basket.

As stated earlier, no procedures exist for the second disposal option for the used fuel canisters. Presumably, the procedure for cleaning the canisters would be the same, after which they would be placed in a plastic-lined box for transport to the smelting operation.

\subsubsection{Time-Motion Study}

A time-motion study for encapsulation of the fuel was performed. During the encapsulation process, dose rates are not expected to change dramatically. Therefore, the major focus was to estimate the number of fuel canisters that could be changed during a typical shift. Additionally, it was necessary to calculate both the time required to perform each function and the dose associated with it.

The original time-motion study assumed that repackaging and encapsulation would be performed primarily in the discharge chute area. In this evaluation, those activities have been relocated to the Technical Viewing Pit.

\section{Preparing Equipment}

The first part of the procedure is to prepare the equipment. This includes checking the nitrogen supply (15 s), checking the corrosion inhibitor system (15 min), checking the Dynafor scale and validating its accuracy $(10 \mathrm{~min})$, and checking the closed circuit television (CCTV) system. If problems are identified, additional time is required. Adding inhibitor requires $15 \mathrm{~min}$. Replacing the nitrogen bottle requires 15 min because a new bottle must be retrieved by a fitter. If the workers are in anti-C clothing, they would not leave the basin during bottle replacement. Changing the battery on the Dynafor requires $15 \mathrm{~min}$. Again, most of the time is required to retrieve the new battery. One person could complete the equipment preparation.

\section{Repackaging Fuel}

The next part of the procedure is to repackage the fuel. This part of the procedure is repeated for several canisters during a shift. 
1. Survey chains, rails, and stiffbacks. This part of the procedure could be performed simultaneously with the preparing equipment step. Estimated time for the RPT to perform the survey is $15 \mathrm{~min}$.

2. Pick up canister of fuel. If the fuel is directly beneath an opening in the grating, this procedure requires $1 \mathrm{~min}$. Most of the fuel, however, is not directly below an opening and an offset hook must be used to snare the canister. Using the offset hook requires up to $5 \mathrm{~min}$ or more if the water has become cloudy from resuspension of the sludge. The worker in the basin area would complete this part of the procedure.

3. Transport fuel canister to the Technical Viewing Pit. This activity requires $10 \mathrm{~min}$. A significant amount of the sludge could resuspend during transport, causing a visibility problem. Such resuspension, however, is not expected to increase the dose rates. The worker in the basin area would complete this part of the procedure.

4. Mass Balance. This procedure is estimated to take 2 min. The two workers in the Technical Viewing Pit area would complete this task while standing on the platform.

5. Move fuel to packaging table. This part of the procedure takes $30 \mathrm{~min}$ and includes dumping the fuel onto the table (10 min), verifying that the canister is empty ( 2 to $5 \mathrm{~min}$ ), and recording the length of each fuel piece $(15 \mathrm{~min})$. The two workers in the discharge chute area would complete this work. The workers would be positioned on the grating above the Technical Viewing Pit, and the other would be located on the platform. Additional time (10 min) would be needed if fuel falls off of the table in the Technical Viewing Pit or if fuel remains in the old canister (more than $15 \mathrm{~min}$ ). Measurement of the fuel takes longer if visibility is poor (additional $15 \mathrm{~min}$ ).

6. Move fuel to encapsulation station. This includes removing broken fuel, aligning the fuel in the packager $(1 \mathrm{~min})$, plunging the fuel into the new canister $(1 \mathrm{~min})$, weighing the newly loaded fuel canister ( $1 \mathrm{~min}$ ), and transporting the fuel to the encapsulation station $(5 \mathrm{~min})$. These estimated times presume clear visibility. If the water is cloudy, 10 additional min may be needed. The two workers in the Technical Viewing Pit area would complete this work.

7. Videorecord contents in canister. This step requires a maximum of $1 \mathrm{~min}$. The two workers in the discharge chute area would complete this work, with one worker positioned above the discharge chute and the other located on the platform.

8. Record canister information. This activity requires up to $30 \mathrm{sec}$. The two workers in the discharge chute area would complete this work; with one worker positioned above the discharge chute and the other located on the platform. 


\section{Encapsulating Fuel}

The next part of the procedure is to encapsulate the fuel. This work is performed primarily by two individuals on the Technical Viewing Pit grating.

1. Prepare canister covers. This process requires $1 \mathrm{~min}$. It includes lowering them to the new canister, and installing the covers. The two workers in the Technical Viewing Pit area would complete this work.

2. Install canister covers. This involves lowering the covers to the canister individually and tightening the cover onto the canister. Poor visibility increases the time to $15 \mathrm{~min}$. The two workers in the Technical Viewing Pit area would complete this work.

3. Purge with nitrogen and inject corrosion inhibitor. This process requires $3 \mathrm{~min}$. If either of the covers does not seal, then the defective cover must be replaced. Replacing the cover takes 15 min and requires an HPT in addition to the two workers in the Technical Viewing Pit area. Removing a defective cover is one instance that may cause dose rates to change. Past experience has shown that nearly $10 \%$ of the covers did not seal. If the canister is defective, then the entire encapsulation process must be repeated. After the purging and injection are complete, an additional person (a supervisor) must initial a record.

4. Videorecord encapsulated canister. This includes weighing the covered canister and requires 2 min. The two workers in the Technical Viewing Pit area would complete this work.

\section{Securing Equipment}

The last part of the procedure is to secure the equipment. This involves turning off the Dynafor scale and the CCTV console. The required time is one minute for one person.

Personnel interviewed were unaware of the procedures for cleaning and crushing the old canisters. A time-and-motion study for that procedure is needed.

Overall, past experience has shown that a maximum of about 30 canisters can be encapsulated in one shift if visibility is clear. Reduced visibility drastically reduces the number of canisters that can be encapsulated. It is likely that no canisters will be processed on days with very poor visibility.

\subsubsection{Dose Projection}

The dose calculations described in Section 3.3.4 are summarized and discussed in this section. The calculations were intended to estimate the change in ambient dose rate caused by changing the basin's water level. The calculations were also meant to estimate the relative contribution from the basin water, the bathtub ring, the primary header, and the return lines. Finally, the dose savings realized by placing a water shield on the discharge chute platform were estimated. 
The results of the calculations for contaminated concrete surfaces that extend 2 in. $(5 \mathrm{~cm})$ above the water line are summarized in Table 3.3 These data show that the bathtub ring is the primary contributor to dose in the discharge chute (DC) area. The presence of the added lead shielding results in lower dose rates on the west side of the platform compared with those on the east side. It can also be seen that work on the grating will result in higher doses than work on the platform. The lead shielding does not reduce the dose rate significantly during work performed while standing on the grating.

The results shown in Table 3.3 also indicate that the primary contributor to the dose rate in the Technical View Pit (TVP) area is the overhead piping. The highest dose rate is estimated to be below the dual return lines, each of which have measured contact dose rates of $90 \mathrm{mR} / \mathrm{h}$. Raising the water level in the TVP will not reduce the dose rate in that area. However, raising the water level will decrease the dose rate just outside the entrance to the TVP where workers are likely to congregate between tasks.

The distance that the bathtub ring extends above the water is not precisely known. Because of this uncertainty, a sensitivity analysis was completed for various water levels below the nominal water level. The results of these studies are summarized in Tables 3.4 through 3.7. Again, the dose is caused primarily by the bathtub ring, and, as expected, the dose rates increase as more of the ring is exposed. Based on measured dose rates above the basin, which average about $15 \mathrm{mrem} / \mathrm{h}$, it is suspected that, with the water level at $16 \mathrm{ft}$, the amount of bathtub ring exposed above the water line is around 4 in. $(10.2 \mathrm{~cm})$.

To estimate the dose savings associated with raising the basin water level, calculations were performed for various water levels. The results of these calculations are presented in Tables 3.8 and 3.9. Raising the water level to a point 6 in. $(15.2 \mathrm{~cm})$ above the bathtub ring source will reduce the dose rate from the bathtub ring at the grating above the discharge chute by a factor of 3 without noticeably raising the dose rate from the basin water source. Raising the water level to a position 12 in. $(30.5 \mathrm{~cm})$ above the current water level will reduce the dose rate from the ring by a factor of 9 compared with the current level, while increasing the dose rate from the basin water by only $10 \%$. Raising the water level to a point $18 \mathrm{in} .(45.7 \mathrm{~cm})$ above the bathtub ring source will reduce the dose rate from the bathtub ring by more than a factor of 20 , while raising the dose rate from the basin water by only $10 \%$. However, with the water level $12 \mathrm{in} .(30.5 \mathrm{~cm})$ or more above the source, the primary dose rate sources are the return lines and the primary water header. Raising the water level by $18 \mathrm{in} .(45.7 \mathrm{~cm})$ does not seem warranted because the benefits in dose savings are diminished. Based on these calculations, the optimum water level appears to be $12 \mathrm{in}$. $(30.5 \mathrm{~cm})$ above the bathtub ring source. Assuming that the current water level exposes 4 in. $(10.2 \mathrm{~cm})$ to 6 in. $(15 \mathrm{~cm})$ of the bathrub ring, the water level should be raised 168 in. $(45.7 \mathrm{~cm}$ ) above the current water level. 
Table 3.3. Dose Rates at Current Water Level

\begin{tabular}{||l|c|c|c|c||}
\hline \multicolumn{1}{|c|}{ Position } & $\begin{array}{c}\text { Ring Dose, } \\
\text { mrem/h }\end{array}$ & $\begin{array}{c}\text { Piping Dose, } \\
\text { mrem/h }\end{array}$ & $\begin{array}{c}\text { Water Dose, } \\
\text { mrem/h }\end{array}$ & $\begin{array}{c}\text { Total Dose, } \\
\text { mrem/h }\end{array}$ \\
\hline DC ${ }^{(a)}$ Grating, East & $6.3(66 \%)$ & $2.4(25 \%)$ & $0.9(9 \%)$ & 9.6 \\
\hline DC Grating, Middle & $7.1(68 \%)$ & $2.4(23 \%)$ & $0.9(9 \%)$ & 10.4 \\
\hline DC Grating, West & $6.7(72 \%)$ & $1.9(20 \%)$ & $0.7(8 \%)$ & 9.3 \\
\hline DC Platform, East & $5.2(58 \%)$ & $3.0(34 \%)$ & $0.7(8 \%)$ & 8.9 \\
\hline DC Platform, Middle & $3.9(55 \%)$ & $2.8(38 \%)$ & $0.6(8 \%)$ & 7.3 \\
\hline DC Platform, West & $2.1(45 \%)$ & $2.3(49 \%)$ & $0.3(6 \%)$ & 4.7 \\
\hline Central Basin & $2.7(49 \%)$ & $0.8(15 \%)$ & $2.0(36 \%)$ & 5.5 \\
\hline $\begin{array}{l}\text { Basin Near Support } \\
\text { Structure }\end{array}$ & $10.5(81 \%)$ & $0.9(7 \%)$ & $1.5(12 \%)$ & 12.9 \\
\hline 50 cm from TVP(b) & $5.8(53 \%)$ & $4.0(37 \%)$ & $1.1(10 \%)$ & 10.9 \\
\hline $\begin{array}{l}\text { TVP: Above Gate 1 } \\
\text { Pool }\end{array}$ & $0.0(0 \%)$ & $13.2(96 \%)$ & $0.5(4 \%)$ & 13.7 \\
\hline $\begin{array}{l}\text { TVP: Above } \\
\text { Support }\end{array}$ & $0.0(0 \%)$ & $19.3(97 \%)$ & $0.7(3 \%)$ & 20 \\
\hline TVP: Below Pipes & $0.0(0 \%)$ & $48.5(99 \%)$ & $0.5(1 \%)$ & 49 \\
\hline $\begin{array}{l}\text { (a) DC = discharge chute } \\
\text { (b) TVP = Technical Viewing Pit }\end{array}$ & & & \\
\hline
\end{tabular}

The final calculation was performed to determine the dose saved by installing a 16 -in $(40.6-\mathrm{m})$ thick water shield, with a height of $6 \mathrm{ft}(1.8 \mathrm{~m})$, along the back of the discharge chute platform. Note that under this scenario the dose rates would not change at either the central basin or support structure locations; therefore, these points are not included in Table 3.11. The calculations show that the water dose is reduced by a maximum of $20 \%$, and typically $10 \%$, at the grating in the work area above the discharge chute. For workers on the platform, the dose will be reduced by as much as $50 \%$, but with a typical reduction of $20 \%$. 
Table 3.4. Dose Rates When Water Level Is 16 Inches $(40.6 \mathrm{~cm})$ Below Current Water Level

\begin{tabular}{||l|c|c|c|c||}
\hline \multicolumn{1}{|c|}{ Position } & $\begin{array}{c}\text { Ring Dose, } \\
\mathrm{mrem} / \mathrm{h}\end{array}$ & $\begin{array}{c}\text { Piping Dose, } \\
\mathrm{mrem} / \mathrm{h}\end{array}$ & $\begin{array}{c}\text { Water Dose, } \\
\mathrm{mrem} / \mathrm{h}\end{array}$ & $\begin{array}{c}\text { Total Dose, } \\
\mathrm{mrem} / \mathrm{h}\end{array}$ \\
\hline DC $^{(\mathrm{a})}$ Grating, East & $15.6(83 \%)$ & $2.4(13 \%)$ & $0.8(4 \%)$ & 18.8 \\
\hline DC Grating, Middle & $18.6(85 \%)$ & $2.4(11 \%)$ & $0.8(4 \%)$ & 21.8 \\
\hline DC Grating, West & $16.8(87 \%)$ & $1.9(16 \%)$ & $0.6(3 \%)$ & 19.3 \\
\hline DC Platform, East & $13.7(79 \%)$ & $3.0(17 \%)$ & $0.6(3 \%)$ & 17.3 \\
\hline DC Platform, Middle & $11.0(77 \%)$ & $2.8(20 \%)$ & $0.5(3 \%)$ & 14.3 \\
\hline DC Platform, West & $6.8(72 \%)$ & $2.3(24 \%)$ & $0.3(3 \%)$ & 9.4 \\
\hline Central Basin & $7.9(75 \%)$ & $0.8(8 \%)$ & $1.9(18 \%)$ & 10.6 \\
\hline $\begin{array}{l}\text { Basin Near Support } \\
\text { Structure }\end{array}$ & $24.6(91 \%)$ & $0.9(3 \%)$ & $1.5(6 \%)$ & 27.0 \\
\hline (a) DC = discharge chute & & & \\
\hline
\end{tabular}

Table 3.5. Dose Rates When Water Level Is 8 Inches $(20.3 \mathrm{~cm})$ Below Current Water Level

\begin{tabular}{||l|c|c|c|c||}
\hline \multicolumn{1}{|c|}{ Position } & $\begin{array}{c}\text { Ring Dose, } \\
\mathrm{mrem} / \mathrm{h}\end{array}$ & $\begin{array}{c}\text { Piping Dose, } \\
\mathrm{mrem} / \mathrm{h}\end{array}$ & $\begin{array}{c}\text { Water Dose, } \\
\mathrm{mrem} / \mathrm{h}\end{array}$ & $\begin{array}{c}\text { Total Dose, } \\
\mathrm{mrem} / \mathrm{h}\end{array}$ \\
\hline DC $^{(a)}$ Grating, East & $11.1(73 \%)$ & $2.4(20 \%)$ & $0.9(7 \%)$ & 12.3 \\
\hline DC Grating, Middle & $12.6(76 \%)$ & $2.4(18 \%)$ & $0.8(6 \%)$ & 13.2 \\
\hline DC Grating, West & $11.9(79 \%)$ & $1.9(15 \%)$ & $0.6(6 \%)$ & 13.1 \\
\hline DC Platform, East & $9.5(66 \%)$ & $3.0(27 \%)$ & $0.7(6 \%)$ & 11.0 \\
\hline DC Platform, Middle & $7.6(64 \%)$ & $2.8(31 \%)$ & $0.5(5 \%)$ & 9.1 \\
\hline DC Platform, West & $4.6(56 \%)$ & $2.3(39 \%)$ & $0.3(5 \%)$ & 5.9 \\
\hline Central Basin & $6.5(64 \%)$ & $0.8(11 \%)$ & $1.9(26 \%)$ & 7.4 \\
\hline $\begin{array}{l}\text { Basin Near Support } \\
\text { Structure }\end{array}$ & $18.0(86 \%)$ & $0.9(5 \%)$ & $1.4(9 \%)$ & 16.6 \\
\hline (a) DC = discharge chute & & & \\
\hline
\end{tabular}

Rev. 2 
Table 3.6. Dose Rates When Water Level Is 4 Inches $(10.2 \mathrm{~cm})$ Below Current Water Level

\begin{tabular}{|l|c|c|c|c||}
\hline \multicolumn{1}{|c|}{ Position } & $\begin{array}{c}\text { Ring Dose, } \\
\mathrm{mrem} / \mathrm{h}\end{array}$ & $\begin{array}{c}\text { Piping Dose, } \\
\mathrm{mrem} / \mathrm{h}\end{array}$ & $\begin{array}{c}\text { Water Dose, } \\
\mathrm{mrem} / \mathrm{h}\end{array}$ & $\begin{array}{c}\text { Total Dose, } \\
\mathrm{mrem} / \mathrm{h}\end{array}$ \\
\hline DC Grating, East & $9.0(73 \%)$ & $2.4(20 \%)$ & $0.9(7 \%)$ & 12.3 \\
\hline DC Grating, Middle & $10.0(76 \%)$ & $2.4(18 \%)$ & $0.8(6 \%)$ & 13.2 \\
\hline DC Grating, West & $10.4(79 \%)$ & $1.9(15 \%)$ & $0.8(6 \%)$ & 13.1 \\
\hline DC Platform, East & $7.3(66 \%)$ & $3.0(27 \%)$ & $0.7(6 \%)$ & 11.0 \\
\hline DC Platform, Middle & $5.8(64 \%)$ & $2.8(31 \%)$ & $0.5(5 \%)$ & 9.1 \\
\hline DC Platform, West & $3.3(56 \%)$ & $2.3(39 \%)$ & $0.3(5 \%)$ & 5.9 \\
\hline Central Basin & $4.7(64 \%)$ & $0.8(11 \%)$ & $1.9(26 \%)$ & 7.4 \\
\hline $\begin{array}{l}\text { Basin Near Support } \\
\text { Structure }\end{array}$ & $14.2(86 \%)$ & $0.9(5 \%)$ & $1.5(9 \%)$ & 16.6 \\
\hline \begin{tabular}{l} 
(a) DC = discharge chute \\
\hline
\end{tabular} & & & & \\
\hline
\end{tabular}

Table 3.7. Dose Rates When Water Level Is 2 Inches $(5 \mathrm{~cm})$ Below Current Water Level

\begin{tabular}{||l|c|c|c|c||}
\hline \multicolumn{1}{|c|}{ Position } & $\begin{array}{c}\text { Ring Dose, } \\
\mathrm{mrem} / \mathrm{h}\end{array}$ & $\begin{array}{c}\text { Piping Dose, } \\
\mathrm{mrem} / \mathrm{h}\end{array}$ & $\begin{array}{c}\text { Water Dose, } \\
\mathrm{mrem} / \mathrm{h}\end{array}$ & $\begin{array}{c}\text { Total Dose, } \\
\mathrm{mrem} / \mathrm{h}\end{array}$ \\
\hline DC Grating, East & $7.7(70 \%)$ & $2.4(22 \%)$ & $0.9(8 \%)$ & 11.0 \\
\hline DC Grating, Middle & $8.7(73 \%)$ & $2.4(20 \%)$ & $0.9(8 \%)$ & 12.0 \\
\hline DC Grating, West & $8.1(76 \%)$ & $1.9(18 \%)$ & $0.7(7 \%)$ & 10.7 \\
\hline DC Platform, East & $6.5(64 \%)$ & $3.0(29 \%)$ & $0.7(7 \%)$ & 10.2 \\
\hline DC Platform, Middle & $4.9(59 \%)$ & $2.8(34 \%)$ & $0.6(7 \%)$ & 8.3 \\
\hline DC Platform, West & $2.8(52 \%)$ & $2.3(43 \%)$ & $0.3(6 \%)$ & 5.4 \\
\hline Central Basin & $3.7(58 \%)$ & $0.8(13 \%)$ & $1.9(30 \%)$ & 6.4 \\
\hline $\begin{array}{l}\text { Basin Near Support } \\
\text { Structure }\end{array}$ & $12.7(84 \%)$ & $0.9(6 \%)$ & $1.5(10 \%)$ & 15.1 \\
\hline (a) DC = discharge chute & & & \\
\hline
\end{tabular}


Table 3.8. Dose Rates When Water Level Is 6 Inches $(15.2 \mathrm{~cm})$ Above Top of Source

\begin{tabular}{||l|c|c|c|c||}
\hline \multicolumn{1}{|c|}{ Position } & $\begin{array}{c}\text { Ring Dose, } \\
\text { mrem/h }\end{array}$ & $\begin{array}{c}\text { Piping Dose, } \\
\text { mrem/h }\end{array}$ & $\begin{array}{c}\text { Water Dose, } \\
\text { mrem/h }\end{array}$ & $\begin{array}{c}\text { Total Dose, } \\
\text { mrem } / \mathrm{h}\end{array}$ \\
\hline DC $^{(a)}$ Grating, East & $2.2(40 \%)$ & $2.4(44 \%)$ & $0.9(16 \%)$ & 5.5 \\
\hline DC Grating, Middle & $2.2(40 \%)$ & $2.4(44 \%)$ & $0.9(16 \%)$ & 5.5 \\
\hline DC Grating, West & $2.1(45 \%)$ & $1.9(40 \%)$ & $0.7(15 \%)$ & 4.7 \\
\hline DC Platform, East & $1.3(25 \%)$ & $3.0(59 \%)$ & $0.8(16 \%)$ & 5.1 \\
\hline DC Platform, Middle & $0.6(15 \%)$ & $2.8(68 \%)$ & $0.7(17 \%)$ & 4.1 \\
\hline DC Platform, West & $0.4(13 \%)$ & $2.3(77 \%)$ & $0.3(10 \%)$ & 3.0 \\
\hline Central Basin & $0.1(3 \%)$ & $0.8(27 \%)$ & $2.1(70 \%)$ & 3.3 \\
\hline $\begin{array}{l}\text { Basin Near Support } \\
\text { Structure }\end{array}$ & $3.7(61 \%)$ & $0.9(15 \%)$ & $1.5(25 \%)$ & 6.1 \\
\hline (a) DC = discharge chute & & & \\
\hline
\end{tabular}

Table 3.9. Dose Rates When Water Level Is 12 Inches $(30.5 \mathrm{~cm})$ Above Current Water Level

\begin{tabular}{||l|c|c|c|c||}
\hline \multicolumn{1}{|c|}{ Position } & $\begin{array}{c}\text { Ring Dose, } \\
\mathrm{mrem} / \mathrm{h}\end{array}$ & $\begin{array}{c}\text { Piping Dose, } \\
\mathrm{mrem} / \mathrm{h}\end{array}$ & $\begin{array}{c}\text { Water Dose, } \\
\mathrm{mrem} / \mathrm{h}\end{array}$ & $\begin{array}{c}\text { Total Dose, } \\
\mathrm{mrem} / \mathrm{h}\end{array}$ \\
\hline $\mathrm{DC}^{(\mathrm{a})}$ Grating, East & $0.7(17 \%)$ & $2.4(59 \%)$ & $1.0(24 \%)$ & 4.1 \\
\hline DC Grating, Middle & $0.8(20 \%)$ & $2.4(59 \%)$ & $0.9(22 \%)$ & 4.1 \\
\hline DC Grating, West & $0.8(24 \%)$ & $1.9(56 \%)$ & $0.7(21 \%)$ & 3.4 \\
\hline DC Platform, East & $0.4(10 \%)$ & $3.0(71 \%)$ & $0.8(19 \%)$ & 4.2 \\
\hline DC Platform, Middle & $0.1(3 \%)$ & $2.8(78 \%)$ & $0.7(19 \%)$ & 3.6 \\
\hline DC Platform, West & $0.0(0 \%)$ & $2.3(85 \%)$ & $0.4(15 \%)$ & 2.7 \\
\hline Central Basin & $0.0(0 \%)$ & $0.8(28 \%)$ & $2.1(72 \%)$ & 2.9 \\
\hline $\begin{array}{l}\text { Basin Near Support } \\
\text { Structure }\end{array}$ & $1.5(38 \%)$ & $0.9(23 \%)$ & $1.5(38 \%)$ & 3.9 \\
\hline (a) DC = discharge chute & & & \\
\hline
\end{tabular}

Rev. 2 
Table 3.10. Dose Rates When Water Level Is 18 Inches $(45.7 \mathrm{~cm})$ Above Current Water Level

\begin{tabular}{||l|c|c|c|c||}
\hline \multicolumn{1}{|c|}{ Position } & $\begin{array}{c}\text { Ring Dose, } \\
\mathrm{mrem} / \mathrm{h}\end{array}$ & $\begin{array}{c}\text { Piping Dose, } \\
\mathrm{mrem} / \mathrm{h}\end{array}$ & $\begin{array}{c}\text { Water Dose, } \\
\mathrm{mrem} / \mathrm{h}\end{array}$ & $\begin{array}{c}\text { Total Dose, } \\
\mathrm{mrem} / \mathrm{h}\end{array}$ \\
\hline DC $^{(\mathrm{a})}$ Grating, East & $0.3(8 \%)$ & $2.4(65 \%)$ & $1.0(27 \%)$ & 3.7 \\
\hline DC Grating, Middle & $0.3(8 \%)$ & $2.4(67 \%)$ & $0.9(25 \%)$ & 3.6 \\
\hline DC Grating, West & $0.2(7 \%)$ & $1.9(66 \%)$ & $0.8(29 \%)$ & 2.9 \\
\hline DC Platform, East & $0.1(3 \%)$ & $3.0(75 \%)$ & $0.9(23 \%)$ & 4.0 \\
\hline DC Platform, Middle & $0.0(0 \%)$ & $2.8(78 \%)$ & $0.8(22 \%)$ & 3.6 \\
\hline DC Platform, West & $0.0(0 \%)$ & $2.3(50 \%)$ & $2.3(50 \%)$ & 4.6 \\
\hline Central Basin & $0.0(0 \%)$ & $0.8(28 \%)$ & $2.1(72 \%)$ & 2.9 \\
\hline $\begin{array}{l}\text { Basin Near Support } \\
\text { Structure }\end{array}$ & $0.5(17 \%)$ & $0.9(30 \%)$ & $1.6(53 \%)$ & 3.0 \\
\hline \begin{tabular}{l} 
(a) DC = discharge chute \\
\hline
\end{tabular} & & & & \\
\hline
\end{tabular}

Table 3.11. Dose Rates When Water Is at Current Level and Water Shield Is in Place

\begin{tabular}{||l|c|c|c|c||}
\hline \multicolumn{1}{|c|}{ Position } & $\begin{array}{c}\text { Ring Dose, } \\
\mathrm{mrem} / \mathrm{h}\end{array}$ & $\begin{array}{c}\text { Piping Dose, } \\
\mathrm{mrem} / \mathrm{h}\end{array}$ & $\begin{array}{c}\text { Water Dose, } \\
\mathrm{mrem} / \mathrm{h}\end{array}$ & $\begin{array}{c}\text { Total Dose, } \\
\mathrm{mrem} / \mathrm{h}\end{array}$ \\
\hline DC $^{(\mathrm{a})}$ Grating, East & $6.2(65 \%)$ & $2.4(25 \%)$ & $0.9(9 \%)$ & 9.5 \\
\hline DC Grating, Middle & $6.4(67 \%)$ & $2.4(25 \%)$ & $0.7(7 \%)$ & 9.5 \\
\hline DC Grating, West & $6.5(72 \%)$ & $1.9(21 \%)$ & $0.6(7 \%)$ & 9.0 \\
\hline DC Platform, East & $4.4(57 \%)$ & $3.0(39 \%)$ & $0.3(4 \%)$ & 7.7 \\
\hline DC Platform, Middle & $2.1(41 \%)$ & $2.8(55 \%)$ & $0.2(4 \%)$ & 5.1 \\
\hline DC Platform, West & $2.0(44 \%)$ & $2.3(51 \%)$ & $0.2(4 \%)$ & 4.5 \\
\hline (a) DC = discharge chute & & & \\
\hline
\end{tabular}


Table 3.12 - Dose Summary per Canister Using the Discharge Chute for Encapsulation

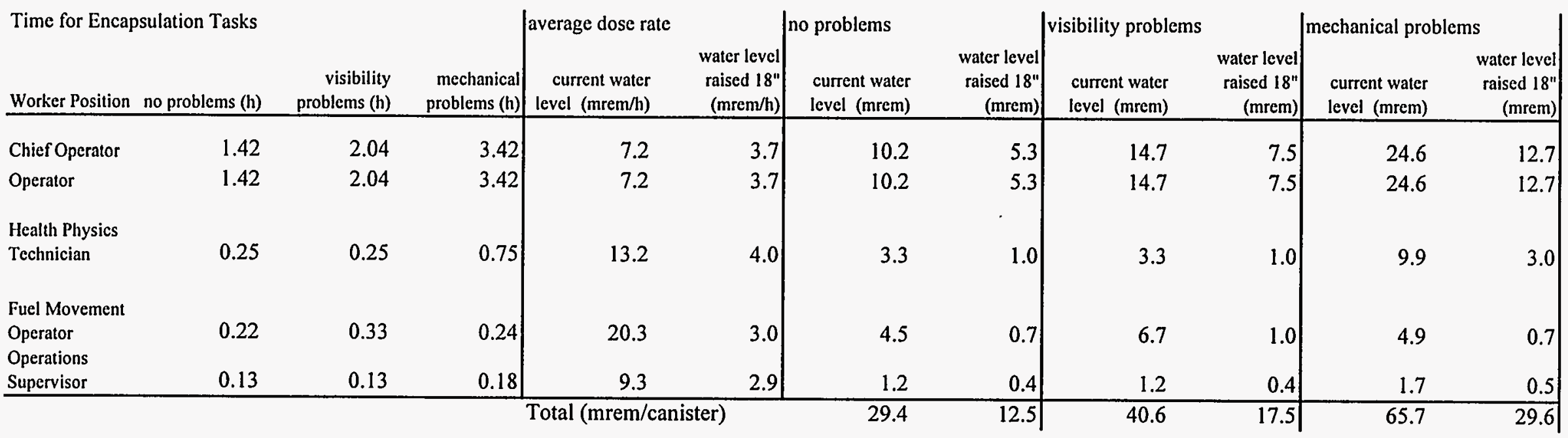

in

Table 3.13 - Dose Summary per Canister Using the Technical Viewing Pit for Encapsulation

\begin{tabular}{|c|c|c|c|c|c|c|c|c|c|c|c|}
\hline \multicolumn{4}{|c|}{ Time for Encapsulation Tasks } & \multirow{2}{*}{$\begin{array}{c}\text { average dose rate } \\
\text { current water } \\
\text { level }(\mathrm{mrem} / \mathrm{h}) \\
\end{array}$} & \multirow{2}{*}{\multicolumn{2}{|c|}{\begin{tabular}{r|l} 
water level & no problems \\
raised 18 & \\
$(\mathrm{mrem} / \mathrm{h})$ & current water \\
level $(\mathrm{mrem})$ \\
\end{tabular}}} & \multirow{2}{*}{\multicolumn{2}{|c|}{\begin{tabular}{r|r}
$\begin{array}{r}\text { water level } \\
\text { raised } 18 " \\
(\mathrm{mrem})\end{array}$ & $\begin{array}{r}\text { current water } \\
\text { level (mrem) }\end{array}$ \\
\end{tabular}}} & \multirow{2}{*}{$\begin{array}{r}\text { water level } \\
\text { raised } 18^{\prime \prime} \\
(\mathrm{mrem})\end{array}$} & \multicolumn{2}{|c|}{ mechanical problems } \\
\hline Worker Position & no problems (h) & $\begin{array}{r}\text { visibility } \\
\text { problems (h) }\end{array}$ & $\begin{array}{r}\text { mechanical } \\
\text { problems (h) }\end{array}$ & & & & & & & $\begin{array}{l}\text { current water } \\
\text { level (mrem) }\end{array}$ & $\begin{array}{r}\text { water level } \\
\text { raised } 18 " \\
(\mathrm{mrem}) \\
\end{array}$ \\
\hline Chief Operator & 1.42 & 2.04 & 3.42 & 15.8 & 11.0 & 22.4 & 15.6 & 32.1 & 22.4 & 53.9 & 37.6 \\
\hline Operator & 1.42 & 2.04 & 3.42 & 15.8 & 11.0 & 22.4 & 15.6 & 32.1 & 22.4 & 53.9 & 37.6 \\
\hline $\begin{array}{l}\text { Health Physics } \\
\text { Technician }\end{array}$ & 0.25 & 0.25 & 0.75 & 13.2 & 4.0 & 3.3 & 1.0 & 3.3 & 1.0 & 9.9 & 3.0 \\
\hline $\begin{array}{l}\text { Fuel Movement } \\
\text { Operato } \\
\text { Operations }\end{array}$ & 0.22 & 0.33 & 0.24 & 20.3 & 3.0 & 4.5 & 0.7 & 6.7 & 1.0 & 4.9 & 0.7 \\
\hline Supervisor & 0.13 & 0.13 & $\frac{0.18]}{7}$ & $\frac{9.3}{\text { Total (mrem/cani }}$ & 2.9 & $\frac{1.2}{53.7}$ & \begin{tabular}{r|}
0.4 \\
33.3
\end{tabular} & $\begin{array}{r}1.2 \\
75.5\end{array}$ & \begin{tabular}{r|}
0.4 \\
47.2
\end{tabular} & $\frac{1.7}{124.2}$ & $\frac{0.5}{79.5}$ \\
\hline
\end{tabular}


The dose calculations 'were combined with the data obtained during the time-motion study for the encapsulaton campaign to quantify the effect of mechanical problems or visibility problems. In addition, the dose effect of raising the water by $18 \mathrm{in} .(45 \mathrm{~cm})$ was also determined both with and without mechanical or visibility problems. The dose projections are summarized in Table 3.12.

The projection suggests that raising the water level to a height that is $14 \mathrm{in} .(35 \mathrm{~cm})$ above the top of the source (raising the water level $18 \mathrm{in}$. [45 cm]) will reduce the total collective dose by a factor of 3 , regardless of any mechanical or visibility problems encountered if the encapsulation activities were performed in the discharge chute.

A dose projection was also completed for disposal of the empty canisters. Disposal was assumed to take place in the dummy elevator pit in the northeast corner of the K-East Basin. Doses were estimated for two scenarios. The first scenario assumed that the water level remained at its current level. Remediation of the water return lines and primary water header was not included in this scenario. The dose rate for operations occurring above the basin (moving the empty canisters to the pit) was assumed to be $7 \mathrm{mrem} / \mathrm{h}$, which is the dose rate over the central basin calculated for a bathtub ring that extends 6 in. $(15 \mathrm{~cm}$ ) above the water line (Table 3.6). The dose in the pit area, where the canisters are washed, removed from the water, surveyed, air dried, and placed in the shipping container, was assumed to be $17 \mathrm{mrem} / \mathrm{h}$. This is the dose rate that was calculated in Table 3.6 near a wall above the basin.

Table 3.13 shows the results of the dose projection for a single canister. The collective dose per canister is estimated to be $10.5 \mathrm{mrem}$. If the total number of canisters is 3668 , then the collective dose for disposal of the fuel canisters is 38.4 person-rem. Table 3.14 contains the details of the collective dose assuming that the basin water remains at its current level.

The second dose projection for disposal of the canisters assumed that the water level was raised $18 \mathrm{in.}(46 \mathrm{~cm})$ above the current level. Remediation of the water return lines and primary water header was not included in this scenario. The dose rate for all operations was assumed to be $3 \mathrm{mrem} / \mathrm{h}$, which is the dose rate above the central basin and near a wall above the basin (Table 3.10). It was further assumed that raising the water level did not change the time required to dispose of the canisters. The collective dose for this scenario was estimated to be $2.2 \mathrm{mrem}$, and the total collective dose for the entire campaign is estimated to be 8.1 person-rem. Table 3.15 contains the details of the collective dose assuming that the basin water level is raised $18 \mathrm{in}$. $(46 \mathrm{~cm})$. Raising the water level 18 in. $(46 \mathrm{~cm})$ will decrease the collective dose associated with disposal of the canisters by nearly a factor of 4 compared with the collective dose associated with canister disposal if the water remains at its current level. 
Table 3.14. Collective Dose Projection for Canister Disposal Campaign, Water at Current Level

\begin{tabular}{||l|c|r|r|r||}
\hline \multicolumn{1}{|c|}{ Worker Position } & $\begin{array}{c}\text { Average Dose } \\
\text { Rate, mrem/h }\end{array}$ & $\begin{array}{c}\text { Total Time, } \\
\mathrm{h}\end{array}$ & $\begin{array}{c}\text { Total Dose, } \\
\text { mrem }\end{array}$ & $\begin{array}{c}\text { Total Person-rem } \\
\text { for Campaign }\end{array}$ \\
\hline $\begin{array}{l}\text { Health Physics } \\
\text { Technician }\end{array}$ & $7 / 17$ & 0.17 & 2.83 & 10.4 \\
\hline $\begin{array}{l}\text { Fuel Movement } \\
\text { Operator }\end{array}$ & $7 / 17$ & 0.35 & 4.28 & 15.7 \\
\hline $\begin{array}{l}\text { Fuel Movement } \\
\text { Operator }\end{array}$ & $7 / 17$ & 0.22 & 3.35 & 12.3 \\
\hline & & & Total Person-rem & 38.4 \\
\hline
\end{tabular}

Table 3.15. Collective Dose Projection for Canister Disposal Campaign, Water Raised 18 Inches $(46 \mathrm{~cm})$

\begin{tabular}{||l|c|r|r|r||}
\hline \multicolumn{1}{|c|}{ Worker Position } & $\begin{array}{c}\text { Average Dose } \\
\text { Rate, mrem/h }\end{array}$ & $\begin{array}{c}\text { Total Time, } \\
\mathrm{h}\end{array}$ & $\begin{array}{c}\text { Total Dose, } \\
\text { mrem }\end{array}$ & $\begin{array}{c}\text { Total Person-rem } \\
\text { for Campaign }\end{array}$ \\
\hline $\begin{array}{l}\text { Health Physics } \\
\text { Technician }\end{array}$ & 3 & 0.17 & 0.50 & 1.8 \\
\hline $\begin{array}{l}\text { Fuel Movement } \\
\text { Operator }\end{array}$ & 3 & 0.35 & 1.05 & 3.97 \\
\hline $\begin{array}{l}\text { Fuel Movement } \\
\text { Operator }\end{array}$ & 3 & 0.22 & 3.6 & 2.43 \\
\hline & & & Total Person-rem & 8.1 \\
\hline
\end{tabular}

\subsection{Review of Related DOE and Commercial Nuclear Industry Experience}

\subsubsection{DOE Experience}

Most of the experience obtained by DOE operations is from the segregation campaign that was undertaken from 1983 to 1984 . Many of the estimates for the time-motion study are based on the work that occurred during this campaign.

Rev. 2 


\subsubsection{Commercial Nuclear Industry Experience}

The following information was obtained from "Nuclear Regulatory Commission Information Notice 90-33: Sources of Unexpected Occupational Radiation Exposures at Spent Fuel Storage (SFS) Pools." Many of the lessons learned at commercial power plants may be applicable to the encapsulation campaign.

\subsubsection{Events Involving Objects Surfacing in the SFS Pool}

In June 1989, several individuals involved in SFS pool cleanup activities at the James A. FitzPatrick Nuclear Power Plant received unexpected radiation exposures from an object floating near the surface of the SFS pool near their work location. Subsequent radiation surveys of the object indicated contact radiation exposure rates of about 1000 roentgens per hour $(R / h)$. The licensee believes that the source of the radiation was a small fragment of radioactive material embedded in a piece of floating material. The floating material probably was a piece of a 5-gallon $(18.9 \mathrm{~L})$ polyethylene container in which irradiated components had been stored underwater for more than a year. Apparently, the polyethylene container began to disintegrate as a result of radiation from the irradiated components stored inside it.

The problem of contaminated objects floating to the surface of SFS pools is not new. In December 1984, complete canister filters from a portable underwater vacuuming system floated at least $15 \mathrm{ft}(4.57 \mathrm{~m})$ toward the top of the spent fuel racks at the Peach Bottom Atomic Power Station. Licensee personnel speculated that the filters may have surfaced before sinking towards the spent fuel storage racks. Although no one received unexpected exposures, this event could have caused significant exposure to personnel.

In May 1987, floating vacuum cleaner filters were also involved in a similar event at the Millstone Nuclear Power Station, Unit 1. During that event, the radiation level on the refueling floor increased momentarily to more than $100 \mathrm{mR} /$ hour, then quickly returned to a normal level of about $10 \mathrm{mR} /$ hour. The high radiation level occurred at the same time that the SFS pool's cooling system was returned to use following valve maintenance. Refilling of the system forced air into the SFS pool through the sparger. The bubbles rose in the pool, causing agitation. The licensee postulated that the agitation forced highly contaminated vacuum cleaner filter cartridges stored in the pool to the surface. These filters contained debris from past cleaning evolutions of the reactor vessel and were suspended by nylon line in the SFS pool. After this event, the licensee decided to remove disposable items from the pool and to replace nylon lines, used for suspending items in the pool, with wire cables.

\subsubsection{Events Involving Highly Radioactive Particles or Fragments of Radioactive Material Removed from SFS Pools}

In December 1987, during reracking operations in the SFS pool at the Diablo Canyon Nuclear Power Plant, Unit 1 , a highly radioactive particle $\left(45.5 \mathrm{mCi}[7.8 \mathrm{MBq}]\right.$ of $\left.{ }^{60} \mathrm{Co}\right)$ was inadvertently removed from the SFS pool. The particle was attached to an air grinder hose that was partially pulled 
from the pool by the diver tender when the grinder hose became entangled with the diver's hose. When the ${ }^{60} \mathrm{Co}$ particle was removed from the pool, the radiation from the particle caused the fuel handling building (FHB) area radiation monitor to alarm, resulting in a shift of the FHB ventilation system to the iodine removal mode. The air grinder hose was not monitored for radiation while it was being removed from the pool. Conservative estimates by the licensee indicated that had the diver tender come in contact ( 0.5 second) with the ${ }^{60} \mathrm{Co}$ particle with his hands, he could have received an extremity dose of 895 mrem.

In October 1989 , personnel at the Byron Station found unexpectedly high activity ${ }^{60} \mathrm{Co}$ particles $(8 \mathrm{mCi}[320 \mathrm{kBq}]$ and $77 \mathrm{mCi}$ [3.1 MBq]) during efforts to decontaminate and remove a portable filter assembly that had been used in an underwater vacuum cleaner to clean the bottom of the SFS pool. Three individuals received unexpected doses to their hands and forearms from these highly radioactive particles. These doses were calculated to be $1.25 \mathrm{rem}, 1.95 \mathrm{rem}$, and $11.6 \mathrm{rem}$.

Highly radioactive materials also have been lifted, unexpectedly, to the surface of SFS pools. At the FitzPatrick plant in February 1987, a worker received an overexposure to the hand during the cutting and removal of in-core instrumentation dry tubes from the reactor vessel. During this operation, the cutting tool was removed from the water for inspection. A piece of highly radioactive dry tube that had been stuck in the tool fell out on the refueling floor. A worker immediately picked up the piece of dry tube and threw it back into the water. As a result of this brief contact with the dry tube, the worker received a radiation dose of about 30 rem to his hand, which exceeds the Nuclear Regulatory Commission's (NRC) limit of 18.75 rem per calendar quarter.

At the Callaway Plant, personnel discovered that an inadequate survey had been made on an underwater fuel elevator following its removal from the SFS pool on April 23, 1989. On April 29, 1989 , a metal object was found to read $1000 \mathrm{R} / \mathrm{h}$ at contact, but the object was shielded by the elevator structure so that only a localized area exceeded $100 \mathrm{mR} / \mathrm{h}$. The highly radioactive metal object was found to be a piece of a torn fuel assembly that had been repaired in the fuel elevator on April 21, 1989. Personnel had attempted to flush the piece out of the bottom of the fuel basket. However, because the piece was never seen in the fuel elevator basket and because no abnormal radiation readings were reported, personnel incorrectly assumed that the piece had been flushed from the elevator basket and was at the bottom of the fuel pool.

\subsubsection{Event Involving Inadvertent Lifting of Highly Radioactive Material by Hoist}

In April 1982 at the Peach Bottom Atomic Power Station, Unit 2, personnel inadvertently lifted a highly radioactive (in the million $\mathrm{R} / \mathrm{h}$ range) control rod blade (CRB) near the surface of the water for 5 to 10 seconds. This event occurred when a hafnium test blade (HFB) was to be moved from the fuel preparation machine to a CRB rack location. This evolution was being supervised by a senior licensed operator. When an operator attempted to move the HFB using the fuel grapple, the operator could not engage the temporary C clamp on the HFB. An auxiliary hoist was subsequently used to successfully move the HFB to the CRB rack location. After completing the HFB movement, 
the operator proceeded to pull the hoist grapple to its normal storage location out of the water. While the hoist was rising, its grapple engaged and picked up an adjacent CRB. The hoist limit switch stopped the upward movement when the grapple was still under $8 \mathrm{ft}(2.49 \mathrm{~m})$ to $10 \mathrm{ft}(3.05 \mathrm{~m})$ of water. At that time the operator, without looking, used the "override" button to bypass the limit switch and raised the grapple with the attached CRB. The area radiation monitor started alarming as the grapple with the CRB approached the surface of the water. Upon hearing the alarm, the refueling floor supervisor looked and saw a brown object approaching the water surface and yelled, "Put it down, put it down." The grapple was stopped before the CRB reached the surface. No radiological surveys were performed during this evolution. However, individuals at the pool area were unnecessarily exposed to radiation. Although these doses were about $300 \mathrm{mrem}$ or less, if the CRB had reached the surface, the doses could have been much greater.

\subsubsection{Event Involving Radiation Streaming}

Underwater tools are designed with flood holes to allow water to fill the hollow sections of tubes. These flood holes provide shielding against radiation streaming from highly radioactive materials that are stored under water. At Indian Point Station, Unit 3, in July 1989, a worker using a tool to perform reconstitution of a spent fuel assembly noticed that a $12-\mathrm{ft}(3.6-\mathrm{cm})$-long $3 / 4$-in $(1.9-\mathrm{cm})$-diameter hollow section of the tool did not have a flood hole. As a result of this equipment design deficiency, the worker received an unplanned exposure. Although the licensee estimated that the worker received a radiation dose of only $30 \mathrm{mrem}$ as a result of this incident, a hollow tool filled with air rather than water can result in much higher doses when the lower end of the tool is under water and near a highly radioactive source.

\subsubsection{Discussion}

A review of licensees' evaluations of these events, the licensees' corrective actions, and feedback from NRC inspectors indicates that the following radiological control considerations can help minimize the possibility of unexpected exposures from radiation sources in SFS pools:

Thorough evaluations of the contents of, and activities involving, SFS pools from a radiological perspective to identify potential unexpected exposure situations

Measures such as task analysis and training to ensure awareness of the potential for uncontrolled, unplanned transfer of highly radioactive materials, including highly radioactive particles, to the surface of SFS pools with the attendant potential for high radiation exposure of workers

Measures to ensure awareness of the need for thorough radiation surveys of all materials being removed from SFS pools

Measures to eliminate or secure floatable material in SFS pools 
- Avoiding the use of containers made of materials (particularly plastics) that are subject to radiation damage and disintegration for the storage of highly radioactive materials in SFS pools If such containers are used, limiting the radiation dose to the container can help to prevent disintegration of the container as a result of radiation damage.

- Measures to ensure that highly radioactive objects stored under water at one end of a line whose other end is secured above the surface of the pool are not unexpectedly pulled to the surface

- Measures to ensure awareness of the need to prevent radiation streaming through hollow sections of handling tools

- Enhanced use of alarming personal dosimeters and of alarming area radiation monitors around SFS pools. 


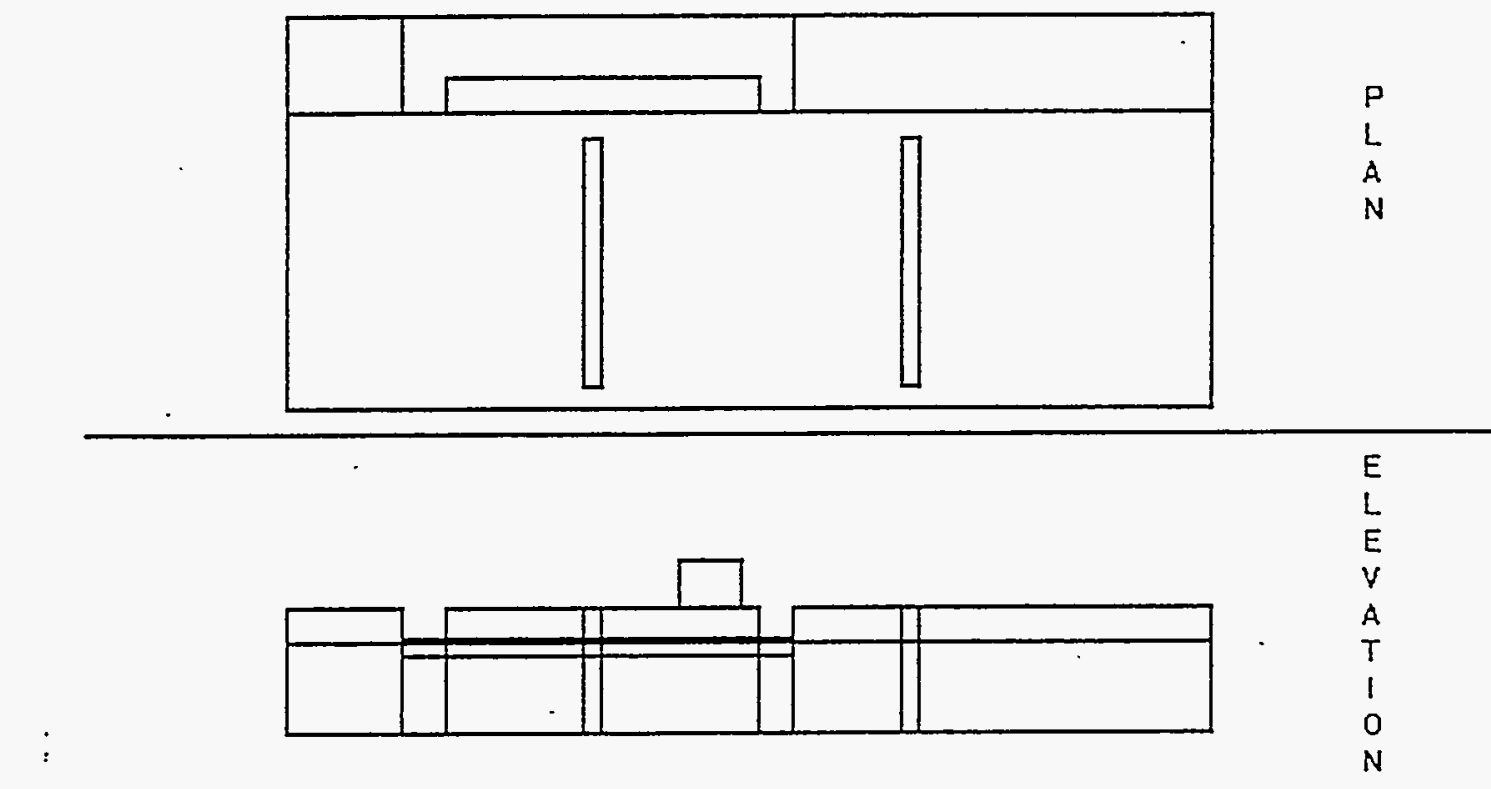

Figure 3.1. Schematic Diagram of the Radiological Model Used to Calculate Doses from the Bathtub Ring and the Basin Water 

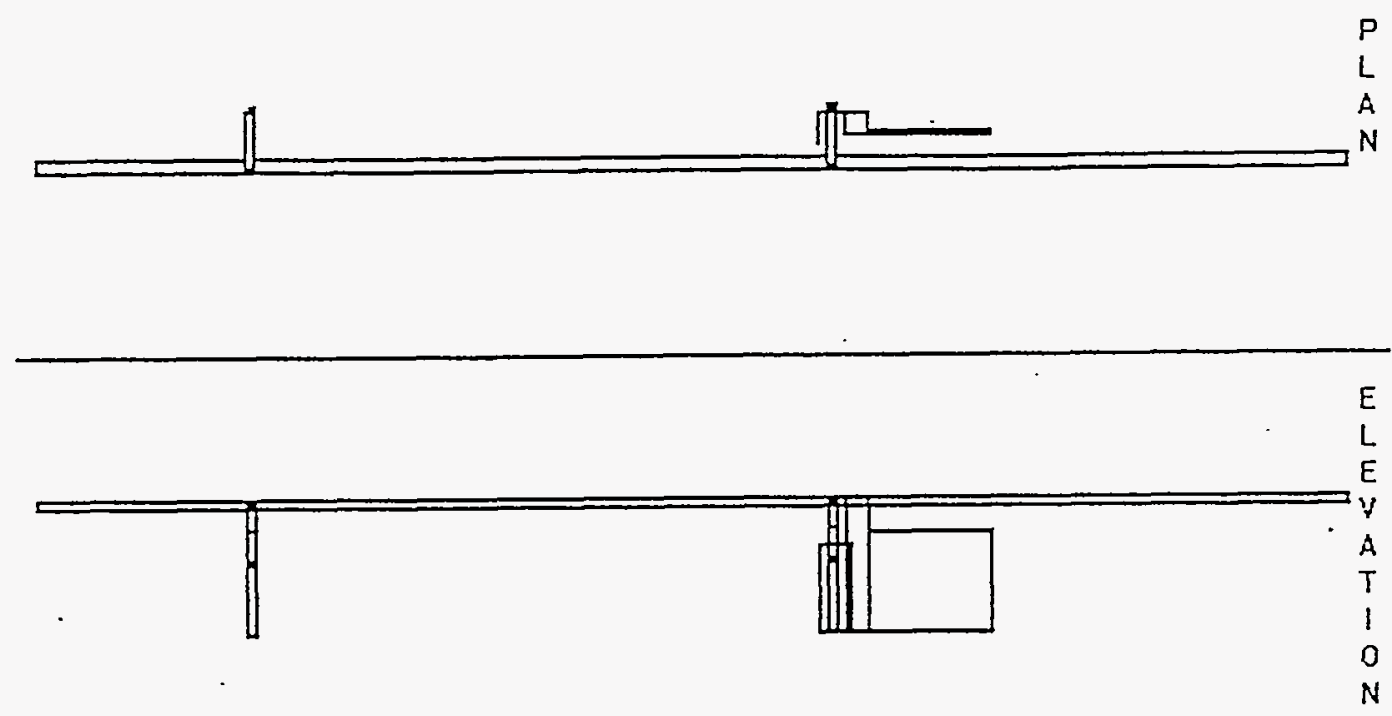

Figure 3.2. Schematic Diagram of the Radiological Model Used to Caiculate Doses from the Water Return Lines and Primary Water Header 


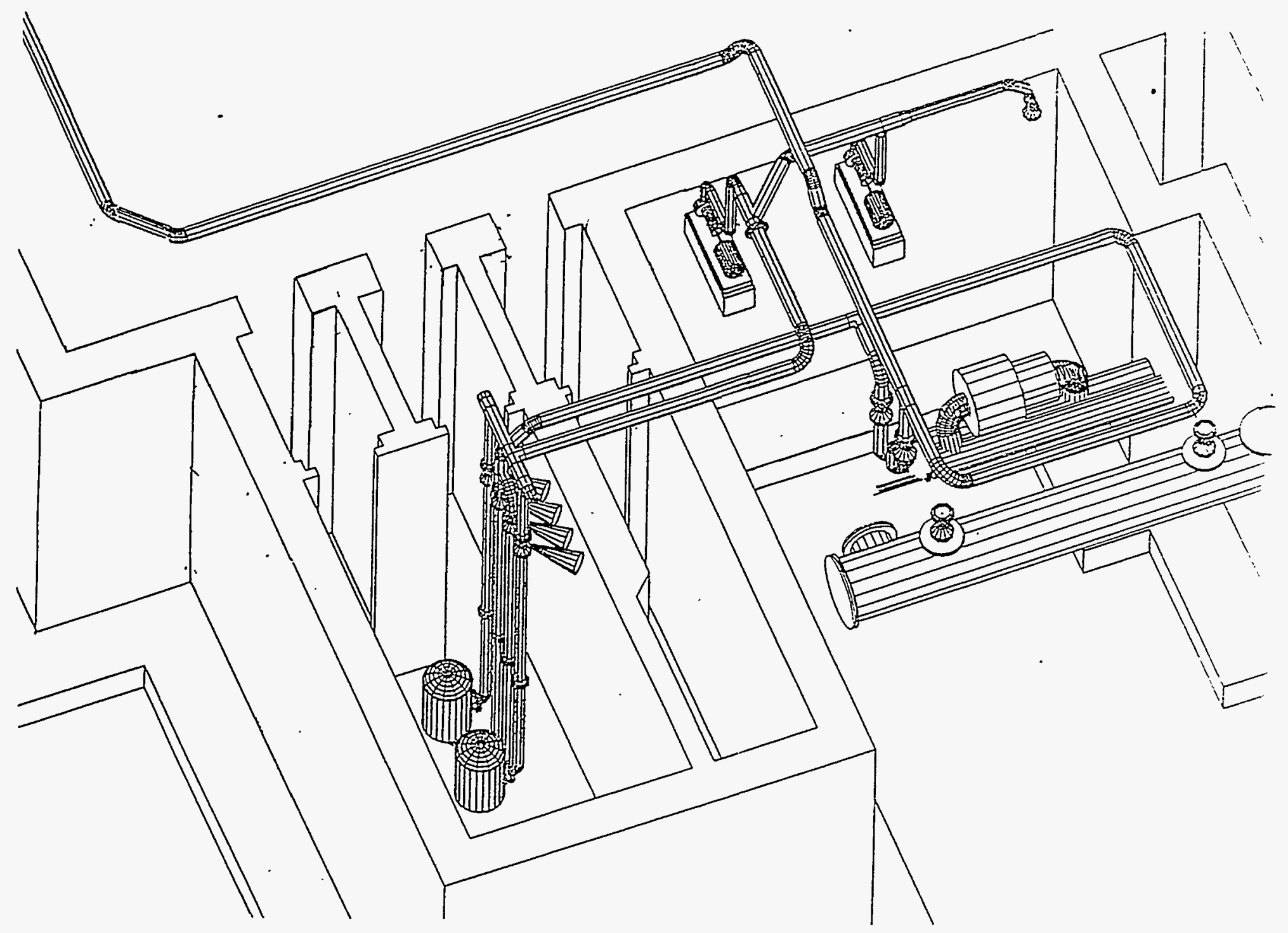

Figure 3.3. Basin Cooling Water System Piping Showing Major Contributors to Personnel Doses in the Technical View Pit Area 


\subsection{Recommendations}

\subsection{Policies, Programs, and Procedures}

Following the evaluation of the WHC policies, programs, and procedures as they relate to the repackaging and fuel encapsulation program, one major recommendation to be incorporated in the revision of the ALARA Program manual was identified.

\subsubsection{Revise Current ALARA Program Manual}

Specifically, address the issues of management's involvement in reviewing, approving, and directing the ALARA process as described in the WHC RCM. Ensure that such involvement is at a level commensurate with the level of anticipated radiation exposure, as determined by complete and appropriate job planning.

Discussion: Because of the significant anticipated individual and collective dose, the highest levels of WHC management, including the WHC President, should document their involvement in the ALARA process by approving the ALARA plan for the $105 \mathrm{KE}$ Repackaging and Fuel Encapsulation Program. These managers should frequently review ALARA performance and acknowledge when dose goals have been exceeded, taking appropriate actions if ALARA goals are not met.

\subsection{Organization, Staffing, and Training}

Three recommendations are being made to support the findings from the review of the organization, staffing, and training with respect to maintaining doses ALARA during the repackaging and encapsulation project.

\subsubsection{Re-evaluate the Pool of Operators Available for Encapsulation}

Re-evaluate the number of qualified operators available for encapsulation, thus keeping individual doses within the Administrative Control Levels established in the Hanford Site Radiological Control Manual (HSRCM).

Discussion: Existing plans are based on expected individual operator doses of between 1500 and $2000 \mathrm{mrem} / \mathrm{y}$. Article 211 of the HSRCM requires approval of the contractor's Senior Site Executive (i.e., President, WHC) to exceed 1000 mrem in a year and approval of the DOE Secretarial Officer (i.e., Assistant Secretary for Environmental Restoration and Waste Management) to exceed 2000 mrem in a year. Article 212 of the HSRCM establishes a Lifetime Control Level of $\mathrm{N}$ rems, where $\mathrm{N}$ represents the worker's age in years. Approval of a Level 1 Manager (i.e., Director, $\mathrm{K}$ Basins) is required to exceed this level. Staffing levels should be based on a goal of maintaining 
individual doses between 1000 and $1500 \mathrm{mrem} / \mathrm{y}$, while retaining flexibility in case operational needs require doses above this level.

\subsubsection{Provide Mockup Training for Fuel Handling}

Establish a mockup training program in the $105 \mathrm{~K}$-West facility to provide operators with an opportunity to practice fuel handling, including the reassembly of inner and outer elements, and reconsolidation of broken fuel elements.

Discussion: One of the most time-consuming tasks in the encapsulation campaign is the manual handling of $\mathrm{N}$-Reactor fuel elements. Providing operators with an opportunity to gain or improve proficiency in fuel handling can reduce the time needed to complete encapsulation.

\subsubsection{Provide Increased Training for Health Physics Technicians}

Include Health Physics Technicians in the Training Program for Basin Operations and Encapsulation to enhance technician knowledge of facility systems and evolutions.

Discussion: Including the Health Physics Technicians in the training program for plant operators will broaden technician knowledge, enhance team-building, promote more effective radiological control, and likely identify opportunities for further individual and collective dose reduction.

\subsection{ALARA Program Implementation}

There are three recommendations made to improve the implementation of the ALARA program while work is being performed in the $105 \mathrm{KE}$ Basin.

\subsubsection{Provide Continuous Dose Rate Monitoring for Workers in the 105 K-East Basin}

Use portable area radiation monitors (ARMs) and pocket alarming dosimeters to monitor for unexpected changes in area dose rates during all work in $105 \mathrm{~K}$-East FSB.

Discussion: A review of commercial industry experience revealed that it is possible to encounter high-activity debris during basin cleanup activities. In some cases, debris contaminated with high levels of activity have floated to the surface and produced significant unplanned exposures. Installed. area radiation monitoring systems are usually inadequate to detect such sources because of poor geometry and a strong $1 / \mathrm{r}^{2}$ dose rate dependence. Portable ARMS should be installed in the discharge chute area to promptly detect large changes in the ambient dose rate. A system of alarming dosimeters with remote monitoring capability would provide necessary radiological monitoring and reduce the need for HPTs in the basin areas. 


\subsubsection{Provide ALARA Areas for Workers}

Identify low dose rate areas ("ALARA Areas") within the $105 \mathrm{~K}$-East FSB and continually provide clear instruction to workers to remain in these areas when they are not actively required for encapsulation work.

Discussion: It is likely that the operator assigned to transport fuel canisters from the storage racks to the discharge chute area will encounter significant waiting periods between transfers. The identification of ALARA Areas, having a dose rate below $1 \mathrm{mrem} / \mathrm{h}$, for personnel to wait between repetitive tasks is a good health physics practice.

\subsubsection{Provide Increased Access to WRAM and Job Control Systems}

Provide the Health Physics Analysts in the M0382 trailer with direct access to the WRAM and Job Control Systems to facilitate timely tracking of personnel doses and more effective work planning.

Discussion: The Environmental Assessment, K Area Encapsulation ALARA Plan (Larson 1993), and other documents commit the 100 Area Health Physics Organization to daily tracking of personnel doses. At present, Health Physics Analysts incur a delay of several hours per day because they do not have access to the WRAM and Job Control Systems from their office spaces. Health Physics Analysts are presently required to review paper copies of work packages. Any changes identified during the radiological review are required to be marked on the paper record and resubmitted through the Job Control System. Providing the Health Physics Analysts with direct access to these systems will improve work planning by allowing the radiological aspects of work to be incorporated at an early phase.

\subsection{Radiological Source Term}

Two recommendations are made for reducing the source term of the basin, thus helping to reduce the doses to ALARA during work at the KE Basin.

\subsubsection{Increase Basin Water Level}

Proceed with the expedited change request for the Operational Safety Requirement (OSR) limit, in the FSB from its current $16 \mathrm{ft} \pm 8$ in. (4.9 $\mathrm{m} \pm$ $20 \mathrm{~cm})$ to $17 \mathrm{ft} 6$ in. \pm 8 in. $(5.3 \mathrm{~m} \pm 20 \mathrm{~cm})$. Prior to increasing the water level, the concrete walls of the basin should be coated with a protective coating, such as epoxy, to prevent absorption of ${ }^{137} \mathrm{Cs}$ into the concrete. To maintain worker doses ALARA during the coating application, water level should be maintained at the current level: between $15 \mathrm{ft} 11 \mathrm{in} .(4.85 \mathrm{~m})$ and $16 \mathrm{ft} 0$ in. $(4.88 \mathrm{~m})$. 
Discussion: The ${ }^{137} \mathrm{Cs}$ contamination of the concrete basin walls accounts for between $45 \%$ and $81 \%$ of the dose rate in areas occupied by workers during the encapsulation campaign. A radiological model of the $105 \mathrm{KE} \mathrm{FSB}$ using the WISE computer code indicates that raising the water level to $17 \mathrm{ft}$ 6 in. $(5.3 \mathrm{~m}$ ) will reduce the contribution of this source by a factor of 20 . Reducing the water level to the OSR minimum prior to application of the protective coating is not recommended because the dose rates are calculated to increase by $50 \%$ from current levels during the coating application.

\subsubsection{Decontaminate the Basin Cooling Water System Piping in the Discharge Chute Area}

Install connections on the line 8 in. $(20 \mathrm{~cm})$ BW-A-12 to allow for decontamination of this line and its branch lines, 6 in. $(15 \mathrm{~cm}) \mathrm{BW}-\mathrm{A}-13$ and $6 \mathrm{in} .(15 \mathrm{~cm})$ BW-A-14, and proceed with decontamination of this piping using high-pressure water sprays.

Discussion: Because of the presence of air-saturated water at low flow velocities, general corrosion has occurred in the piping of the basin's cooling water system. The accumulation of radioactive contamination in the corrosion layer of this piping has resulted in high dose rates in its vicinity ( $60 \mathrm{mrem} / \mathrm{h}$ to $110 \mathrm{mrem} / \mathrm{h}$ at or near contact with the piping.) According to a radiological model of the basin, this source accounts for between $7 \%$ and $49 \%$ of the dose rate in areas occupied by workers during the encapsulation campaign. Some temporary shielding has been used; however, a significant portion of 8 in. $(20 \mathrm{~cm}) \mathrm{BW}-\mathrm{A}-12$ is unshielded. While some benefit could be realized through the use of additional temporary shielding, a reduction in the piping radiological source term is preferable.

\subsection{Current Operations}

Several recommendations regarding current support functions were developed based on observations and time-motion studies. Most of the recommendations are related to rigging and toolhandling operations.

\subsubsection{Cartridge Filter Replacement}

Use removable guide pins to align the lid of the cartridge filter housing during reinstallation.

Discussion: The time-motion study indicated that proper alignment with remote tools currently in use is difficult and time-consuming. One remedy would be to design a mechanical pressure-retention guide pin and socket that could be attached to one of the ears to which the eye bolts are attached, thus allowing removal from the ears after the lid is in place. This will speed the alignment process because the guide pin would bring the lid into position, prevent swinging of the lid, and reduce the visibility demands. 
Install on the hoist a hook of the correct design, which has been size-matched to the lifting ring on the lid, or install on the lid a rigid lifting ring that has been size-matched to the current hoist hook.

Discussion: Operations personnel in the K-Basin area indicated that the hook design was not optimal for the lifting ring on the cartridge filter housing lid. An improved configuration would speed the process of rigging and reduce the time necessary to complete the task.

Install on the hoist a dynamometer of sufficient durability to allow its use for rigging during the entire replacement evolution and make the appropriate procedural changes to take advantage of this technique.

Discussion: Weighing of the cartridge filter is a multi-step process that would be simplified if the dynamometer were capable of lifting the lid and the cartridge and taking the attendant strain of breaking the seal on the lid/housing and on the lower cartridge gasket/housing. In conjunction with this recommendation, it would be necessary to change section $C$ of procedure 59/60-07-9. It would be necessary to insert a step to record the weight of the cartridge after step I.C.4, and replace current steps I.C.13 through I.C.15 with current step I.C.16.

\section{Use a rigid plastic container to wrap the spent cartridge for contamination control purposes.}

Discussion: To cover the cartridge for contamination control purposes, step I.C.16 of procedure 59/60-07-9 should be changed to place the cartridge into a rigid plastic can, which would have to be manufactured for the purpose. The can could have a "clamshell" cap that could be set down on top of the can around the lifting rig, and the can could be sealed with tape or adhesive in a manner that would significantly reduce the time spent next to the can. This would also preclude breakage of the bag from the weight of the cartridge. The can may have to accommodate positioning of the anti-float device referred to in step I.C.18 of the same procedure.

Use a stronger adhesive to attach the housing/cartridge gasket to the cartridge.

Discussion: When preparing the new cartridge in accordance with step I.C.10, using a stronger adhesive agent will prevent the gasket from being mispositioned or falling off during installation. Correct positioning of the gasket prevents basin water from bypassing the filter. Mispositioning, if detected, requires removal of the cartridge from the water; drying, reinstallation and adhesion of the gasket; and reinstallation of the cartridge.

Install quick-release hooks of sufficient strain capacity to support the housing lid and sufficient size to hook easily onto the rail where the chain lanyard is currently attached by bolting it into position. 
Discussion: Currently, the lanyard is secured with a bolt and nut arrangement. Improvement in the design of the lanyard will reduce the time and dexterity necessary to attach the lanyard to the rail. Handling of the lanyard will then be less likely to damage protective rubber or plastic gloves used for contamination control purposes.

\subsubsection{Ion Exchange Column Replacement}

Replace the tools used to thread the column inlet and outlet plugs into the expended column and magnetize either the old or the redesigned tools.

Discussion: Currently used tools are all very worn, with small drive heads. The plugs must be handled very slowly and are very difficult to align properly. The maximum time required to complete this task is reported to be as much as 20 min per connection and the minimum time is 2 min. With careful design of the tool, this could be reduced to a maximum of about 2 min per connection, with the resultant savings of approximately 72 person-minutes per column replaced.

The tools currently in use are of either soft iron or carbon steel, and are easily magnetized. The plugs are of iron/steel construction, and would adhere to the tools sufficiently enough to improve efficiency, even in their current condition. Use of old magnetized tools would minimize dropping of the plugs, even though alignment of the threads would still be difficult. Use of new magnetized tools would virtually eliminate the dropping and alignment problems currently encountered.

Obtain additional spare plugs and connectors for the fittings on the column.

Discussion: Operations personnel stated that accidental dropping of plugs during removal/installation is a common occurrence, resulting in significant delays in the task. If plugs are dropped when sufficient spares are available, retrieving the dropped plugs could then wait until after the columns are removed to the storage caves, when dose rates would be reduced to general area rates. Plant personnel indicated that the plugs and connectors are routinely re-used and are not matched to a particular column. This recommendation could be implemented at low cost for each single column replacement, with no procedural or administrative changes.

Ensure that the column connections are aligned with the access ports of the IXC.

Discussion: Alignment could be ensured by procuring housings that are specific to the IXC at $105 \mathrm{KE}$. If a specific housing cannot be procured, a spacer made of nylon or other non-absorbing material could be placed below the housing. Placement of the spacer would eliminate the additional rigging operation and provide a stationary ${ }_{2}$ rather than suspended, platform for threading in of the lower connection plug.

Use a rigid plastic container instead of a plastic bag to hold the column during preparation for shipment. 
Discussion: The use of the guide tube would be unnecessary, and the container could be sealed much more quickly, resulting in a shorter duration of exposure and at a greater distance, i.e., one person at approximately $1 \mathrm{ft}(0.3 \mathrm{~m})$ and 60 seconds for the can, versus two persons at approximately 6 in. $(0.15 \mathrm{~m})$ and 120 seconds for the current practice as described by plant personnel.

\subsubsection{Ion Exchange Module Replacement}

No recommendations.

\subsubsection{Sand Filter Sampling}

Investigate the feasibility of obtaining sand samples through the existing vent line with a remote sampling tool instead of opening the sand filter housing, or, as an alternative, modify the vent line in accordance with a 1983 memorandum. ${ }^{\text {(a) }}$

Discussion: If feasible, this would virtually eliminate the extensive rigging and testing requirements as currently performed in the procedure. Procedure 59-43-7, "Sample Sand from Sand Filter at 105-KE Without Backwashing Sand Filter," (and, similarly, 59/60-43-3) should be modified.

If the vent line on top of the tank extends without obstruction, or if the vent line could be modified slightly in order to simplify removal of obstructions, then a narrow tool such as a surface-soil boring tool, or a waste drum sampling tool, could be used to draw the sample without removing any equipment or structures except the vent valve. If the tool were also sleeved and supplied with evacuation for contamination control purposes, respiratory protection and contamination control areas would not be necessary.

Thes 1983 memorandum recommended that the tank cover be modified with a tank-top access port above the tank's interior access port. This would require a design modification (cutting of the lid and manufacture of the cover over the new opening) and would not eliminate the need to breach the seal on the access port. However, if modification of the vent line and use of a remote tool is not feasible, this alternative would still significantly reduce the amount of time, effort, and personnel required to perform sampling.

(a) Memorandum [UNC Nuclear Industries], B.H. Lueck to R.A. Winship, "ALARA REVIEW - 105-KE BASIN SORTING PROGRAM," dated February 7, 1983. 


\subsection{References}

10 CFR 835. 1993. U.S. Department of Energy, "Occupational Radiation Protection." U.S. Code of Federal Regulations.

Bechtold, D. B. 1981. KE Fuel Storage Basin Activity Mapping in Support of Exposure Reduction. UNI-1697, United Nuclear Industries, Richland, Washington.

Bricker, W. M. 1991. ALARA Plan for Repackaging and Fuel Encapsulation at 105KE Basin. WHC-SD-NR-PNL-007, 12/2/1991, Westinghouse Hanford Company, Richland, Washington.

Dionne, B. J., et al. 1993. "Comparative ALARA Assessment of Boiling Water and Pressurized Water Reactors." Radiation Protection Management 10(6).

Institute of Nuclear Power Operations (NPO). 1991. Guidelines for Radiological Protection at Nuclear Power Stations. 91-014, Atlanta, Georgia.

International Commission on Radiation Protection (ICRP). 1990. Optimization and Decision-Making in Radiological Protection. ICRP Publication 55, Pergamon Press, New York.

Johnson, J. R. 1977. Behavior of Spent Nuclear Fuel in Water Pool Storage. BNWL-2256, Pacific Northwest Laboratory. Richland, Washington.

Langevin, M. J. 1993. Canister Disposal Options Report. Draft. K Basins Engineering. Richland, Washington.

National Council Radiation Protection and Measurements (NCRP). 1993. Limitation of Exposure to Ionizing Radiation. Report No. 116, Washington, D.C.

Reece, W. D., S. D. Miller, and L. A. Sigalla. 1989. Development of the WISE and SIMPLE Codes for Estimating Radioactive Waste Inventory and Shielding. Version 1.0. NP-6226-CCML, Battelle, Pacific Northwest Laboratories, Richland, Washington.

U.S. Department of Energy (DOE). 1980. A Guide to Reducing Radiation Exposure to As Low As Reasonably Achievable (ALARA). DOE/EV/1830-T5, Washington, DC.

U.S. Department of Energy (DOE). 1988. Radiation Protection for Occupational Workers. DOE Order 5480.11. Washington, DC.

U.S. Department of Energy (DOE). 1988. Health Physics Manual of Good Practices for Reducing Radiation Exposure to As Low As Reasonably Achievable (ALARA). PNL-6577, Pacific Northwest Laboratory. Richland, Washington.

U.S. Department of Energy (DOE). 1992. U.S. Department of Energy Radiological Control Manual. DOE/EH-0256T, Washington, DC. 
U.S. Department of Energy (DOE). 1992. Environmental Assessment of 1050-KE and 105-KW Basins Fuel Encapsulation and Repackaging, 100-K Area, Hanford Site. DOE/EA-0535, Richland, Washington.

U.S. Department of Energy (DOE). 1993. Implementation Guide, Occupational ALARA Program. G-10 CFR 835/B2-Rev.0. Washington DC.

U.S. Department of Energy (DOE). 1994. Occupational Dose Reduction at Department of Energy Contractor Facilities: Bibliography of Selected Readings in Radiation Protection and ALARA. EH-0364T/BNL-43228, Volume 5, Washington DC.

U.S. Department of Energy (DOE). Occupational Dose Reduction at Department of Energy contractor Facilities: Study of ALARA Programs - Status 1990. DOE/EH-0277T, Washington, DC.

U.S. Department of Energy (DOE). Occupational Dose Reduction at Department of Energy contractor Facilities: Study of ALARA Programs - Good Practice.Documents. DOE/EH-0278T, Washington, DC.

U.S. Nuclear Regulatory Commission (NRC). 1990. Sources of Unexpected Occupational Radiation Exposures At Spent Fuel Storage Pools. IN 90-33, Washington, D.C.

U.S. Nuclear Regulatory Commission Information Notice 90-33: Sources of Unexpected Occupational Radiation Exposures at Spent Fuel Storage (SFS) Pools.

Westinghouse Hanford Company (WHC). 1988. ALARA Program Manual. WHC-CM-4-11, Richland, Washington.

Westinghouse Hanford Company (WHC). 1991. Fuel Encapsulation Environmental Assessment Database. TRAC-0091, Richland, Washington.

Westinghouse Hanford Company (WHC). 1992. Cost Benefit Analysis at Westinghouse Hanford Company. WHC-SA-1533-FP, Richland, Washington.

Westinghouse Hanford Company (WHC). KE/KW Fuel Encapsulation Task and KE Basin Cleanup Task Management Plan. Rev. 2 WHC-SP-0591, Richland, Washington. 


\section{Procedures}

The following list of procedures were referenced or consulted for the preparation of this report:

Westinghouse 100K Basin Procedures:

\begin{tabular}{|c|c|c|c|}
\hline $\begin{array}{c}\text { Procedure } \\
\text { No. }\end{array}$ & Title & $\begin{array}{l}\text { Rev. } \\
\text { No. }\end{array}$ & $\begin{array}{r}\text { MMDDYY } \\
\text { Approved }\end{array}$ \\
\hline $59-07-42$ & $\begin{array}{l}\text { Repackage and Encapsulate N-Reactor Fuel at 105-KE } \\
\text { Basin }\end{array}$ & NEW & $04 / 05 / 93$ \\
\hline $59-43-7$ & $\begin{array}{l}\text { Sample Sand from Sand Filter at } 105-\mathrm{KE} \text { Without } \\
\text { Backwashing Sand Filter }\end{array}$ & NEW & $11 / 05 / 93$ \\
\hline $59 / 60-07-9$ & $\begin{array}{l}\text { Replace and Dispose of Primary Recirculation Cartridge } \\
\text { Filters at } 100-\mathrm{KE} / \mathrm{KW}\end{array}$ & 4 & $11 / 16 / 90$ \\
\hline $59-07-28$ & $\begin{array}{l}\text { Remove Ion Exchange Column(s) from Service and Store } \\
\text { in Lead Caves at } 105-\mathrm{KE}\end{array}$ & 2 & $11 / 19 / 93$ \\
\hline $59 / 60-43-4$ & Sample Sludge from North Loadout Pit at $105-\mathrm{KE} / \mathrm{KW}$ & 2 & $10 / 16 / 89$ \\
\hline $59 / 60-43-3$ & Sample Sand from Sand Filter at $105-\mathrm{KE} / \mathrm{KW}$ & 1 & $09 / 21 / 89$ \\
\hline $59-07-23$ & Replace Ion Exchange Module at 105-KE & 3 & $01 / 06 / 94$ \\
\hline $59-07-53$ & $\begin{array}{l}\text { Isolate, Drain and Return to Service Ion Exchange } \\
\text { Module (IXM) System at KE }\end{array}$ & NEW & $06 / 04 / 93$ \\
\hline $59-07-45$ & Clean and Crush Canisters Stored in 105-KE Basin & NEW & $02 / 23 / 93$ \\
\hline $59 / 60-07-43$ & $\begin{array}{l}\text { Remove Waste from the } 105-\mathrm{KE} / \mathrm{KW} \text { Storage Basins for } \\
\text { Burial }\end{array}$ & 1 & $03 / 24 / 93$ \\
\hline $59-07-10$ & Dispose of Ion Exchange Columns, 100-KE Only & 3 & $03 / 15 / 90$ \\
\hline $60-07-11$ & Dispose of Ion Exchange Columns, 100-KW Only & 2 & $03 / 21 / 90$ \\
\hline $59 / 60-07-35$ & $\begin{array}{l}\text { Remove Crushed MKI and MKII Cansiters from 105- } \\
\text { KE/KW Storage Basins }\end{array}$ & 2 & $01 / 28 / 93$ \\
\hline $59 / 60-43-2$ & Take Samples of Sludge in K-Area Basins & 4 & $10 / 16 / 89$ \\
\hline $59-07-48$ & Operate Two IXMs at $105-\mathrm{KE}$ & 1 & $05 / 25 / 93$ \\
\hline $60-07-21$ & $\begin{array}{l}\text { Isolate, Drain and Return to Service Ion Exchange } \\
\text { Module (IXM) System at KW }\end{array}$ & 2 & $06 / 04 / 93$ \\
\hline $59 / 60-46-1$ & $\begin{array}{l}\text { Package Low Level Solid Radioactive Waste in } 4 \times 4 \times 8 \\
\text { Boxes }\end{array}$ & NEW & $06 / 16 / 93$ \\
\hline $59-06-1$ & $\begin{array}{l}\text { Perform Routine Patrol of } 105-\text { KE Irradiated Fuel Storage } \\
\text { Facilities }\end{array}$ & 5 & $08 / 27 / 93$ \\
\hline
\end{tabular}




\begin{tabular}{|c|c|c|c|}
\hline $\begin{array}{l}\text { Procedure } \\
\text { No. }\end{array}$ & Title & $\begin{array}{l}\text { Rev. } \\
\text { No. }\end{array}$ & $\begin{array}{r}\text { MMDDYY } \\
\text { Approved }\end{array}$ \\
\hline $59-07-47$ & Sludge Transfer & 5 & $11 / 19 / 93$ \\
\hline $59 / 60-07-32$ & $\begin{array}{l}\text { Prepare Ion Exchange Modules (IXM) for Shipment to } \\
\text { Burial }\end{array}$ & 2 & $12 / 06 / 93$ \\
\hline $59-07-42$ & $\begin{array}{l}\text { Repackage and Encapsulate N-Reactor Fuel at } 105-\mathrm{KE} \\
\text { Basin }\end{array}$ & NEW & 04/05/93 \\
\hline $59-07-45$ & Clean and Crush Canisters Stored in 105-KE Basin & NEW & $02 / 23 / 93$ \\
\hline $59 / 60-07-35$ & $\begin{array}{l}\text { Remove Crushed MKI and MKII Cansiters from } \\
\text { 105-KE/KW Storage Basins }\end{array}$ & 2 & $01 / 28 / 93$ \\
\hline $59 / 60-46-1$ & $\begin{array}{l}\text { Package Low Level Solid Radioactive Waste in } 4 \times 4 \times 8 \\
\text { Boxes }\end{array}$ & NEW & $06 / 16 / 93$ \\
\hline
\end{tabular}




\section{DISTRIBUTION}

No. of

Copies

OFFSITE

2 DOE/Office of Scientific and Technical Information

J. W. Baum

Brookhaven National Laboratory

Upton, NY 11973-5000

T. A. Kahn

Brookhaven National Laboratory

Upton, NY 11973-5000

\section{ONSITE}

27 Pacific Norhtwest Laboratory

J.L. Ethridge R3-85

G.R. Cicotte K3-56

J.S. Durham K3-56

E.E. Hickey K3-56

P.S. Stansbury K3-56

S.M. Short R3-85

G.J. Vargo (15) K3-56

Publishing Coordination

Technical Report Files (5)
No. of

Copies

24 Westinghouse Hanford Company

C.J. Alderman N1-21

M.K. Bravard N1-21

W.F. Brehm H5-67

B.S. Carlisle X3-71

R.F. Creed N1-55

J. L. Daily II R3-81

K.W. Davis X0-35

J.I. Dearing N1-32

J.C. Fordham N1-32

J.R. Frederickson R3-86

M. Kaviani K3-60

R.J. Kuhta X3-76

M.J. Langevin X3-76

D.K. Lemke X3-65

S.S. Lewis $\quad \mathrm{X} 3-60$

C.D. Lucas $\quad \mathrm{X} 0-35$

J.D. Mathews X3-61

C. T. Miller X3-72

W. J. Millsap H5-68

F.W. Moore N1-25

T. J. Ruane X3-65

C.A. Thompson X3-72

J.E. Truax X3-71

M.J. Wiemers R3-86

Distr. 1 